\title{
Development of Potent Inhibitors of Fatty Acid Amide Hydrolase Useful for the Treatment of Neuropathic Pain
}

\author{
Margherita Brindisi, ${ }^{[a]}$ Giuseppe Borrelli+ ${ }^{+a]}$ Simone Brogi ${ }^{+}{ }^{[a]}$ Alessandro Grillo ${ }^{+},{ }^{\text {[a] }}$ \\ Samuele Maramai ${ }^{\left[{ }^{[a]}\right.}$ Marco Paolino, ${ }^{[a]}$ Mascia Benedusi, ${ }^{[b]}$ Alessandra Pecorelli, ${ }^{[c]}$ \\ Giuseppe Valacchi, ${ }^{[b, c]}$ Lorenzo Di Cesare Mannelli, ${ }^{[d]}$ Carla Ghelardini, ${ }^{[\mathrm{d}]}$ Marco Allarà, ${ }^{[\mathrm{e}, \mathrm{f}]}$ \\ Alessia Ligresti, ${ }^{[\mathrm{e}]}$ Patrizia Minetti, ${ }^{[\mathrm{g}]}$ Giuseppe Campiani, ${ }^{[\mathrm{[a]}}$ Vincenzo di Marzo, ${ }^{[\mathrm{e}, \mathrm{h}]}$ \\ Stefania Butini, ${ }^{*[a]}$ and Sandra Gemma ${ }^{[a]}$
}

\begin{abstract}
The unique role of fatty acid amide hydrolase (FAAH) in terminating endocannabinoid (EC) signaling supports its relevance as a therapeutic target. Inhibition of EC metabolizing enzymes elicits indirect agonism of cannabinoid receptors (CBRs) and therapeutic efficacy devoid of psychotropic effects. Based on our previous ligands, and aiming at the discovery of new selective FAAH inhibitors, we developed a series of 12 new compounds characterized by functionalized tricyclic scaffolds. All the developed compounds display negligible activity on monoacylglycerol lipase (MAGL) and CBRs. The most potent FAAH inhibitors of the newly developed series, 6-oxo-5,6-dihydro-4Hbenzo[f]pyrrolo[1,2-a][1,4] diazepin-9-yl-6-phenylhexylcarbamate $(5 \mathrm{~h})$ and 4-oxo-5,6-dihydro-4H-benzo[f]pyrrolo[1,2-a][1,4]diaze-
\end{abstract}

pin-9-yl-(6-phenylhexyl)carbamate (5i) (nanomolar FAAH inhibitors, the latter of which also shows micromolar affinity at the $\left.\mathrm{CB}_{1} \mathrm{R}\right)$, were selected for further studies. Results of cell-based studies on a neuroblastoma cell line (IMR32) demonstrated $\mathbf{5} \mathbf{h}$, $5 \mathbf{i}$, and our reference compound $\mathbf{3}$ ([3-(3-carbamoylpyrrol-1-yl)phenyl] $\mathrm{N}$-(5-phenylpentyl)carbamate) to lack any cytotoxic effect, while all three showed the ability to decrease oxidative stress by reducing the expression of the redox-sensitive transcription factor NF- $\kappa$ B. Encouraged by these data, these compounds were studied in vivo and were dosed orally in a mouse model of neuropathic pain. At $10 \mathrm{mg} \mathrm{kg}^{-1}$ all the compounds were able to relieve the hypersensitivity induced by oxaliplatin.

\section{Introduction}

Fatty acid amide hydrolase (FAAH, EC 3.5.1.99), an integral membrane-bound serine hydrolase, ${ }^{[1-2]}$ is the main catabolic enzyme of the fatty acid ethanolamides (FAEs) such as anandamide (AEA) and oleamide. ${ }^{[3]}$ Other enzymes that contribute to termination of endocannabinoid (EC) action are $\mathrm{N}$-acylethanolamine acid amidase ${ }^{[4]}$ and monoacylglycerol lipase (MAGL). ${ }^{[5]}$ FAEs, together with 2-arachidonoylglycerol, are the main EC signaling lipids, which, by interacting with type- 1 and type-2 cannabinoid receptors $\left(\mathrm{CB}_{1} \mathrm{R}\right.$ and $\left.\mathrm{CB}_{2} \mathrm{R}\right)$, exert biological activity and modulate a variety of physiological processes including pain, inflammation, appetite, motility, sleep, thermoregulation, cognition, and emotional states. ${ }^{[6-7]}$ The analgesic effects of $C B_{1} R$ and $C B_{2} R$ have been known for centuries; ${ }^{[8]}$ however, as with other CBRs agonists, they produce a spectrum of motor and psychotropic side effects mediated by central $C_{1} R$. Accordingly, a valuable therapeutic alternative should elicit the desirable effects of $C B R$ activation, while avoiding the negative effects of global $\mathrm{CB}_{1} \mathrm{R}$ stimulation, through indirect receptor agonism obtained by inactivation of EC-metabolizing enzymes. The relevance of FAAH in the safe management of pain is supported by evidence that faah knockout mice display high AEA levels in the central nervous system (CNS) and show an analgesic phenotype in models of both inflammatory pain (induced by carrageenan) and acute pain (induced by formalin) ${ }_{1}^{[9]}$ together with a decrease in the inflammatory responses, ${ }^{[10]}$ and improved sleep and memory acquisition. ${ }^{[11-12]}$ In fact, FAAH in- 
hibition by increasing the endogenous concentration of its substrates, protracts and potentiates their beneficial (therapeutic) effects, without eliciting the classical $C_{1} R$ agonist side effects (hypomotility, hypothermia, and catalepsy). ${ }^{[13]}$ In 2016, the serious adverse effects observed in a phase I study with an irreversible FAAH inhibitor (BIA 10-2474) led to a temporary suspension of the development of FAAH inhibitors. Shortly thereafter, a report from the US Food and Drug Administration $(F D A)^{[14]}$ concluded that BIA 10-2474 has a peculiar toxicity profile that does not extend to other FAAH inhibitors. In fact, an in-depth reinvestigation uncovered a series of off-target proteins for the same compound. ${ }^{[15]}$

Chronic pain is a major public health problem that has a tremendous impact on the quality of life of the patients, producing a significant economic and social burden. ${ }^{[16]}$ Neuropathic pain (a severe, debilitating and persistent form of chronic pain that may arise from dysfunctional or damaged peripheral nerves, spinal cord, or brain ${ }^{[17]}$ ) is poorly treated by conventional therapeutics, which also exhibit a series of drawbacks and side effects. All the above considerations suggest that the use of FAAH inhibitors may provide a safe and efficient approach for the treatment of painful syndromes including neuropathies. $^{[17]}$

The crystal structure of FAAH enabled in-depth knowledge of the enzyme features and functioning useful for the development of selective inhibitors. The catalytic triad (S241, S217, and K142; human isoform numbering) is accessible through the acyl-binding channel and the "membrane access channel". ${ }^{[18]}$ In proximity to the nucleophilic S241 residue, the oxyanion hole accommodates the carbonyl oxygen atom of amide or ester substrates by establishing hydrogen bonds. The various FAAH inhibitors developed so far can be clustered into two families: irreversible (e.g., carbamates $\mathbf{1} \mathbf{a}^{[19]}$ and $\mathbf{1} \mathbf{b}_{,}{ }^{[20]}$ Figure 1 ) and reversible inhibitors (e.g., $\alpha$-ketooxazole $2{ }^{[21]}$ Figure 1 ). In this context, we recently reported the development of different classes of compounds as inhibitors of EC metabolic enzymes: potent and selective $\mathrm{FAAH}^{[22-23]}$ or $\mathrm{MAGL}^{[24]}$ inhibitors and dual FAAH/MAGL ${ }^{[25]}$ inhibitors useful in different pathological states. $^{[26-27]}$

As a continuation of our efforts in the discovery of FAAH inhibitors, herein we describe the development of pyrrole-based analogues inspired by our previously identified ligands. This new series of compounds ( $5 \mathbf{a}-\mathbf{l}$, Figure 1 and Table 1 ) are based on our structural template, lead compound 3, which was modified in a classical medicinal chemistry approach involving structural rigidification by bridging the phenylpyrrole scaffold. In particular, three types of tricyclic systems were explored: 1) a 6-6-5 system, pyrrolo[1,2-a]quinoxaline (also inspired by the structure of previously developed FAAH/MAGL inhibitors typified by $\left.4^{[25]}\right) ; 2$ ) a 6-6-5 system, pyrrolo[1,2-a]quinoxalin-4(5H)-one substituted at $\mathrm{C} 6$ or $\mathrm{C} 8$; and 3 ) the 6-7-5 systems 4,5-dihydro-6H-benzo[f]pyrrolo[1,2-a][1,4]diazepin-6-one and 5,6-dihydro-4H-benzo[f]pyrrolo[1,2-a][1,4]diazepin-4-one heterocycles, substituted at $\mathbf{C 9}$. These systems were tethered to a piperazinyl urea or a carbamate via phenylhexyl, undecyn$\mathrm{yl}$, or (monofluoro)phenoxyethoxyethyl lateral chains (Figure 1 and Table 1). Below we discuss the synthesis, molecular model-
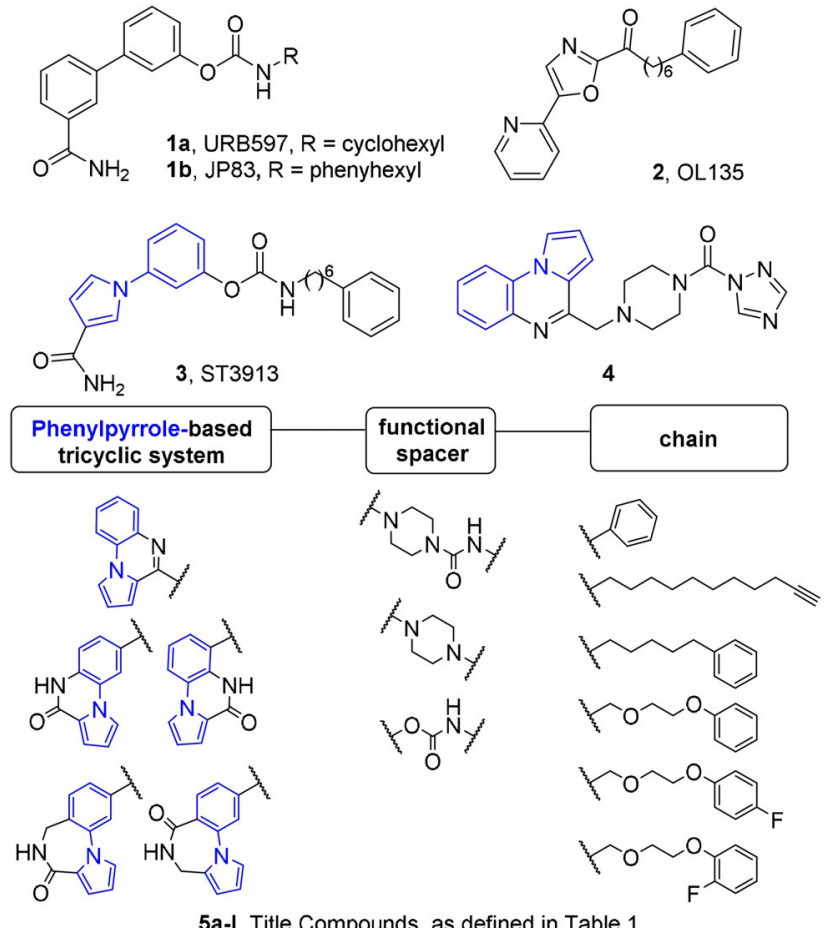

Figure 1. References 1-4 and title compounds 5 a-l.

ing, in vitro and in vivo biological properties of these new FAAH inhibitors.

\section{Results and Discussion}

\section{Chemistry}

The synthesis of compounds $\mathbf{5} \mathbf{a}-\mathbf{I}$ is illustrated in Schemes 1-5. Reaction of pyrroloquinoxalyl intermediate $6^{[28-31]}$ (Scheme 1) with alkyl isocyanates $7 \mathrm{a}-\mathrm{c}$ afforded piperazine carboxamidebased compounds $\mathbf{5} \mathbf{a}-\mathbf{c}$, whereas reaction with the alkyl bromides afforded the alkyl piperazine-based derivatives $\mathbf{5} \mathrm{d}, \mathrm{e}^{[32]}$

For the synthesis of $\mathbf{5} \mathbf{f}$ (Scheme 2) application of the Curtius rearrangement protocol to acid $\mathbf{8}$ with tert-butanol provided the protected aniline 9. After Boc group removal, amine $\mathbf{1 0}$ was converted into the 1-phenylpyrrole derivative 11 by Clauson-Kaas reaction. Reduction of the nitro functionality led to amine 12, which by treatment with triphosgene, provided quinoxalinone 13. Treatment with boron tribromide afforded

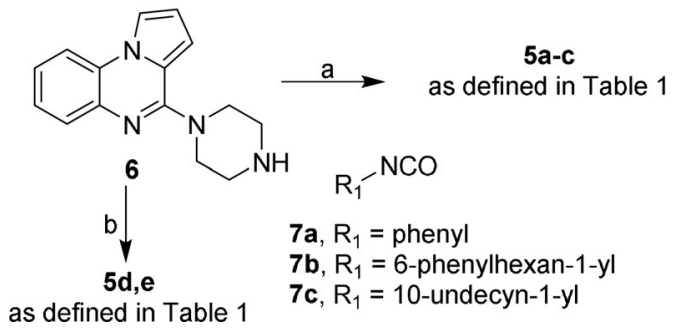

Scheme 1. Reagents and conditions: a) $R_{1} N C O$, TEA, dry THF, reflux, 11 h, 59$62 \%$; b) $\mathrm{R}_{2} \mathrm{Br}$, TEA, MeCN, reflux, $14 \mathrm{~h}, 71-75 \%$. 
Table 1. $\mathrm{IC}_{50}$ and percent displacement values on FAAH and $\mathrm{MAGL}$, as well as $C B_{1} \mathrm{R}$ and $\mathrm{CB}_{2} \mathrm{R}$ for compounds $\mathbf{5}$ a-I and reference compound 3 . ${ }^{\text {[ }}$

\begin{tabular}{|c|c|c|c|c|c|}
\hline \multirow[t]{2}{*}{ Compd } & \multirow[t]{2}{*}{ Structure } & \multicolumn{4}{|c|}{$\mathrm{IC}_{50}$ [nм] (Displacement [\%]) } \\
\hline & & $\mathrm{FAAH}$ & MAGL & $\mathrm{CB}_{1} \mathrm{R}$ & $\mathrm{CB}_{2} \mathrm{R}$ \\
\hline $5 a$ & & $\begin{array}{c}>50 \mu \mathrm{M} \\
(15.4)\end{array}$ & NT & NT & NT \\
\hline $5 \mathrm{~b}$ & & $\begin{array}{c}>50 \mu \mathrm{M} \\
(7.7)\end{array}$ & NT & NT & NT \\
\hline $5 c$ & & $\begin{array}{c}>50 \mu \mathrm{M} \\
(7.19)\end{array}$ & NT & NT & NT \\
\hline $5 d$ & & $\begin{array}{c}>50 \mu \mathrm{M} \\
(12.7)\end{array}$ & NT & NT & NT \\
\hline 5 e & & $\begin{array}{c}>50 \mu \mathrm{M} \\
(5.8)\end{array}$ & NT & NT & NT \\
\hline $5 \mathrm{f}$ & & 520 & NT & $\begin{array}{c}>50 \mu \mathrm{M} \\
(46.2)\end{array}$ & $\begin{array}{c}>50 \mu \mathrm{M} \\
(6.6)\end{array}$ \\
\hline $5 \mathrm{~g}$ & & 460 & NT & $\begin{array}{c}>50 \mu \mathrm{M} \\
(25.7)\end{array}$ & $\begin{array}{c}>50 \mu \mathrm{M} \\
(4.3)\end{array}$ \\
\hline $5 \mathrm{~h}$ & & 83.5 & $\begin{array}{c}>50 \mu \mathrm{M} \\
(0.7)\end{array}$ & $\begin{array}{c}>50 \mu \mathrm{M} \\
(25.3)\end{array}$ & $\begin{array}{c}>50 \mu \mathrm{M} \\
(19.3)\end{array}$ \\
\hline $5 i$ & & 94.1 & $\begin{array}{c}>50 \mu \mathrm{M} \\
(23.7)\end{array}$ & 6730 & 24300 \\
\hline $5 j$ & & 2825.3 & $\begin{array}{c}>10 \mu \mathrm{M} \\
(5.7)\end{array}$ & $\begin{array}{c}>50 \mu \mathrm{M} \\
(49.0)\end{array}$ & $\begin{array}{c}>50 \mu \mathrm{M} \\
(25.5)\end{array}$ \\
\hline $5 \mathrm{k}$ & & 1672.3 & $\begin{array}{c}>10 \mu \mathrm{M} \\
(7.5)\end{array}$ & $\begin{array}{c}>50 \mu \mathrm{M} \\
(42.5)\end{array}$ & $\begin{array}{c}>50 \mu \mathrm{M} \\
(39.3)\end{array}$ \\
\hline 51 & & 2687.3 & $\begin{array}{c}>10 \mu \mathrm{M} \\
(6.8)\end{array}$ & $\begin{array}{c}>50 \mu \mathrm{M} \\
(46.0)\end{array}$ & $\begin{array}{c}>50 \mu \mathrm{M} \\
(37.4)\end{array}$ \\
\hline $3^{[22]}$ & & 0.60 & NA & NA & NA \\
\hline
\end{tabular}

[a] Values are the means of three experiments $(n=3)$, and all SDs not indicated are within 10\%. Percent displacement at the maximum concentration tested is reported in brackets if the $\mathrm{IC}_{50}$ value is $>10$ or $50 \mu \mathrm{m}$. Tests were performed as previously described ${ }^{[25]}$ with $\mathrm{FAAH}$ from rat brain (82.7\% sequence identity and $97.2 \%$ sequence similarity with $h$ FAAH) or MAGL COS from cytosol with 30 and 20 min incubation time at $37^{\circ} \mathrm{C}$, respectively. NT: not tested. NA: not active. 


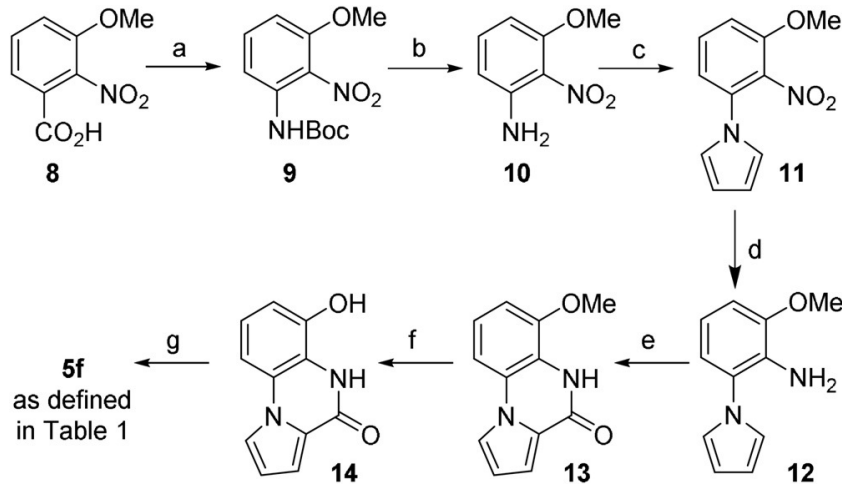

Scheme 2. Reagents and conditions: a) $t \mathrm{BuOH}, \mathrm{DPPA}$, TEA, reflux, $15 \mathrm{~h}, 78 \%$; b) TFA, $0{ }^{\circ} \mathrm{C}, 1.5 \mathrm{~h}, 99 \%$; c) 2,5-dimethoxytetrahydrofuran, $\mathrm{AcOH}, \mathrm{H}_{2} \mathrm{O}, 100{ }^{\circ} \mathrm{C}$ 15 min, 97\%; d) $\mathrm{Fe}^{\circ}, \mathrm{CaCl}_{2}$, EtOH $75 \%, 80^{\circ} \mathrm{C}, 2 \mathrm{~h}, 87 \%$; e) $\mathrm{CO}\left(\mathrm{OCCl}_{3}\right)_{2}$, toluene, $120^{\circ} \mathrm{C}, 2 \mathrm{~h}, 52 \%$; f) $\mathrm{BBr}_{3}, \mathrm{CH}_{2} \mathrm{Cl}_{2},-78 \rightarrow 25^{\circ} \mathrm{C}, 12 \mathrm{~h}, 11 \%$; g) $7 \mathrm{~b}$, TEA THF, $25^{\circ} \mathrm{C}, 16 \mathrm{~h}, 30 \%$.

phenol 14 , which was treated with phenylhexylisocyanate $\mathbf{7 b}$ to afford $\mathbf{5} \mathbf{f}$.

Nitration of the 3-hydroxyphenylacetamide 15 (Scheme 3) led to 16. Sequential hydrolysis of the acetamido group, Clauson-Kaas reaction, and reduction of the nitro functionality provided aminophenol 17. Cyclization carried on with triphosgene afforded derivative $\mathbf{1 8}$, later converted into the urethane $\mathbf{5 g}$.

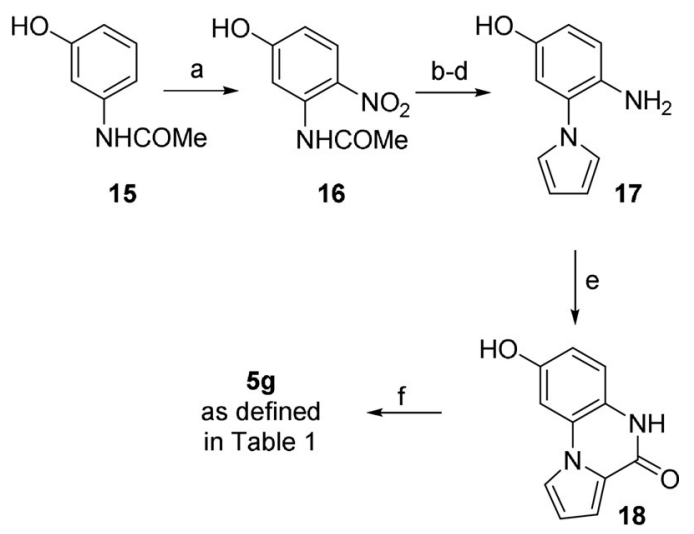

Scheme 3. Reagents and conditions: a) $\mathrm{HNO}_{3}, \mathrm{AcOH}, \mathrm{Ac}_{2} \mathrm{O}, 25^{\circ} \mathrm{C}, 8 \mathrm{~h}, 98 \%$; b) $12 \mathrm{~N} \mathrm{HCl}, 130^{\circ} \mathrm{C}, 5 \mathrm{~h}, 95 \%$; c) $5 \mathrm{~N} \mathrm{HCl}, 2,5$-dimethoxytetrahydrofuran, 1,4dioxane, $110^{\circ} \mathrm{C}$, $20 \mathrm{~min}, 70 \%$; d) $\mathrm{SnCl}_{2} \cdot 2 \mathrm{H}_{2} \mathrm{O}$, EtOAc, $25^{\circ} \mathrm{C}, 2 \mathrm{~h}, 85 \%$; e) $\mathrm{CO}\left(\mathrm{OCCl}_{3}\right)_{2}$, toluene, $120^{\circ} \mathrm{C}, 2 \mathrm{~h}, 36 \%$; f $7 \mathrm{~b}, \mathrm{TEA}, \mathrm{THF}, 25^{\circ} \mathrm{C}, 16 \mathrm{~h}, 10 \%$.

After esterification and nitro group reduction of the nitrocarboxylic acid 19 (Scheme 4) the resulting aniline was subjected to Clauson-Kaas reaction to give intermediate 20. This 1-phenylpyrrole was converted into the 2-cyanopyrrole derivative 21. Selective reduction of the nitrile by treatment with sodium borohydride in the presence of cobalt(II) chloride led to spontaneous cyclization to the pyrrolobenzo[1,4]diazepinone derivative 22. Cleavage of the methyl ether functionality followed by treatment with phenylhexylisocyanate provided $\mathbf{5} \mathbf{h}$.

For the preparation of compounds $\mathbf{5} \mathbf{i}-\mathbf{I}$ (Scheme 5) aryl fluoride $\mathbf{2 3}$ was submitted to aromatic nucleophilic substitution with methyl $1 \mathrm{H}$-pyrrole-2-carboxylate in the presence of<smiles>COC(=O)c1ccc(OC)cc1-n1cccc1C#N</smiles>
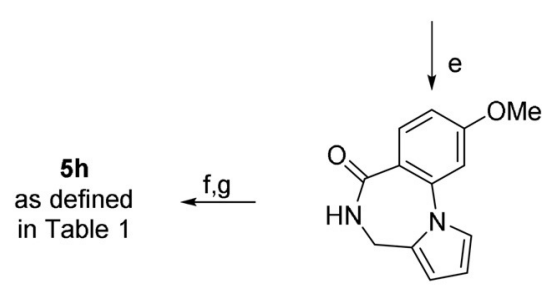

22

Scheme 4. Reagents and conditions: a) $\mathrm{SOCl}_{2}, \mathrm{MeOH}, 25^{\circ} \mathrm{C}, 10 \mathrm{~h}$; b) $\mathrm{SnCl}_{2} \cdot 2 \mathrm{H}_{2} \mathrm{O}$, EtOAc, $25^{\circ} \mathrm{C}, 2 \mathrm{~h}$; c) $5 \mathrm{~N} \mathrm{HCl}, 2,5$-dimethoxytetrahydrofuran, 1,4-dioxane, $110^{\circ} \mathrm{C}, 5 \mathrm{~min}, 87 \%$ (over three steps); d) $(\mathrm{COCl})_{2}, \mathrm{NH}_{2} \mathrm{OH} \cdot \mathrm{HCl}$, pyridine, DMF, 1,2-DCE, $0 \rightarrow 120^{\circ} \mathrm{C}, 10 \mathrm{~h}, 47 \%$; e) $\mathrm{NaBH}_{4}, \mathrm{CoCl}_{2}, \mathrm{MeOH}, 25^{\circ} \mathrm{C}$, $30 \mathrm{~min}, 64 \%$; f) $\mathrm{BBr}_{3}, \mathrm{CH}_{2} \mathrm{Cl}_{2},-78 \rightarrow 25^{\circ} \mathrm{C}, 12 \mathrm{~h}, 50 \%$; g) $7 \mathrm{~b}, \mathrm{TEA}, \mathrm{THF}, 25^{\circ} \mathrm{C}$, $16 \mathrm{~h}, 60 \%$.

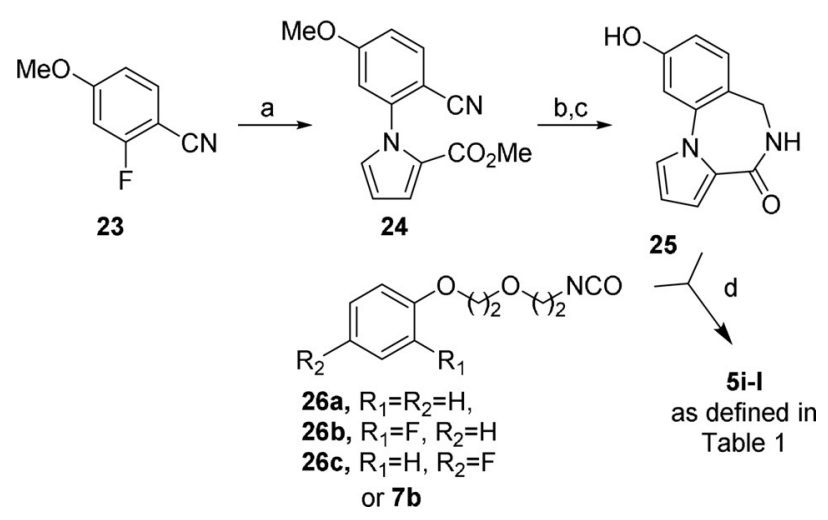

Scheme 5. Reagents and conditions: a) Methyl $1 \mathrm{H}$-pyrrole-2-carboxylate, $\mathrm{Cs}_{2} \mathrm{CO}_{3}$, dry DMF, $50^{\circ} \mathrm{C}, 12 \mathrm{~h}, 30 \%$; b) $\mathrm{NaBH}_{4}, \mathrm{CoCl}_{2}, \mathrm{MeOH}, 25^{\circ} \mathrm{C}, 30 \mathrm{~min}$, $71 \%$; c) $\mathrm{BBr}_{3}$, dry $\mathrm{CH}_{2} \mathrm{Cl}_{2},-78 \rightarrow 25^{\circ} \mathrm{C}, 12 \mathrm{~h}, 50 \%$; d) TEA, dry THF, $25^{\circ} \mathrm{C}, 12 \mathrm{~h}$, 43-55\%.

cesium carbonate. The resulting 1-phenylpyrrole 24 was reduced, cyclized, and treated with boron tribromide, thus providing the pyrrolobenzo[1,4]diazepinone intermediate 25 . Re-

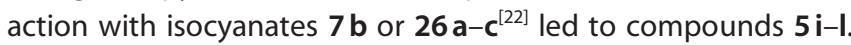

\section{Structure-activity relationship and molecular modeling studies}

The inhibitory potencies of compounds $\mathbf{5} \mathbf{a}-\mathbf{I}$ for $F A A H$ are listed in Table 1. Selectivity toward $M A G L, C B_{1} R$, and $C_{2} R$ was evaluated for the most promising compounds. The new compounds showed an excellent selectivity profile for FAAH over $M A G L, C B_{1} R$, and $C B_{2} R$, with only $\mathbf{5} \mathbf{i}$ revealing single-digit micromolar affinity at $\mathrm{CB}_{1} \mathrm{R}$ and two-digit micromolar affinity at $C_{2} R$. These data confirmed that the presence of an "activated" electrophilic center (such as ureido or carbamoyl moieties) is a crucial requirement for FAAH inhibition potency. In fact, compounds $\mathbf{5 a - e}$, where the electrophilic center is absent $(\mathbf{5 d , e})$ 
or where a urea group is present between the two aliphatic amines $(\mathbf{5} \mathbf{b}, \mathbf{c})$ were found to be inactive. If the urea involved an aniline $(5 \mathrm{a})$ as the carbamoylating moiety, enzyme inhibition was still poor, although slightly higher than that of the other urea-containing analogues of the series. In line with our previous results, the insertion of a carbamate in the developed molecules allowed us to identify a series of selective FAAH inhibitors $(\mathbf{5} \mathbf{f}-\mathbf{I})$ characterized by the presence of different scaffolds supporting the phenol moiety. The influence of polyether lateral chains (as the enzyme carbamoylating entities) was explored for the most promising and synthetically accessible scaffolds, which modulated FAAH inhibitory properties ( $\mathbf{5} \mathbf{j}-\mathbf{I}$ vs. 5 i).

To better understand the structure-activity relationships (SARs) of the developed compounds, we performed molecular docking studies to assess the interactions of the inhibitors with FAAH at the atomic level. We performed an induced-fit docking (IFD) calculation as reported ${ }^{[33-35]}$ to identify the main contacts governing the behavior of our compounds with the enzyme. The data were compared with those obtained by applying the same protocol to our previously described lead $\mathbf{3}$ (see the Supporting Information (SI) and Figure S1). In particular, $\mathbf{5} \mathbf{h}$, one of the most potent compounds of this series, interacts with the FAAH active site by polar and hydrophobic contacts (Figure $2 \mathrm{~A}, \mathrm{~B}$ ). Polar contacts were established by the lactam moiety and the backbones of V270 and C269. In line with the potency of FAAH inhibition of $5 \mathrm{~h} \quad\left(\mathrm{IC}_{50}=83.5 \mathrm{~nm}\right.$, Table 1) the electrophilic moiety is properly placed in front of the catalytic serine residues (S217 and S241) which can establish hydrogen bonds with the carbamate phenate oxygen. The orientation of the carbon of the carbamate portion and its distance from the catalytic S241 residue $(<3 \AA)$ are in agreement with a potential nucleophilic attack. The carbonyl group can establish two hydrogen bonds with 1238 and G239. Furthermore, the phenylhexyl lateral chain could be located in a hydrophobic sub-pocket lined by F192, F381, and F432, producing a double $\pi-\pi$ stacking with F192 and F432. Compound $\mathbf{5 i}$ displayed similar interactions besides a correct orientation toward S241 ( $\pi-\pi$ stacking with F381 and F432, hydrogen bonds with C269 and V270, and interaction with the catalytic S241; Figure $3 \mathrm{~A}, \mathrm{~B})$.

In compounds $\mathbf{5} \mathbf{j}-\mathbf{I}$, the introduction of a polyether tether, for replacing the hexyl chain of $\mathbf{5} \mathbf{i}$, caused a marked decrease in FAAH inhibition. The docking outputs for $\mathbf{5} \mathbf{j}-\mathbf{l}$ clearly confirm the lack of potency (SI Figures S2 A,B, S3 A,B, S4 A,B). The polyether chain is diverted from accommodation in the hydrophobic sub-pocket of the enzyme (see superposition of $\mathbf{5} \mathbf{i}$ and $\mathbf{5} \mathbf{j}$, Figure $3 \mathrm{C}$ ) and prevents the carbamate from establishing an interaction with the catalytic serine residue S241, while still being able to establish two hydrogen bonds (with 1238 and G239 for $\mathbf{5 j}$ and with S193 and G239 for $\mathbf{5 I}$ and $\mathbf{5} \mathbf{k}$ ).

In compound $\mathbf{5 g}$ the restricted 6-6-5 tricyclic system produces a binding mode quite different from that found for the 67-5 system of $\mathbf{5} \mathbf{h}$. The tricyclic system can only form a hydrogen bond with the backbone of C269, and in line with the three-digit nanomolar potency of $\mathbf{5} \mathbf{g}$ (Table 1), it lacks a suitable distance for interaction with S241. The different accommodation of the more planar and bulkier tricyclic system prevents projection of the aliphatic tail into the hydrophobic subpocket (SI Figure S5 A,B). The superposition of the IFD poses of $\mathbf{5 h}$ and $\mathbf{5 g}$ clearly illustrates the described differences (SI Figure $\mathrm{S} 5 \mathrm{C}$ ).

The same is true for compound $\mathbf{5} \mathbf{f}(\mathrm{SI}$ Figure $\mathrm{S} 6 \mathrm{~A}, \mathrm{~B})$. In particular, the tricyclic moiety establishes only one polar contact with T236. The carbamate group interacts with S217 and S241 by two hydrogen bonds, and the phenylhexyl tail forms a double $\pi-\pi$ stacking interaction with F192 and F381.

\section{Cytotoxicity determination and potential antioxidant evalu- ation for $3,5 \mathrm{~h}$, and $5 \mathrm{i}$}

Oxidative stress (OS) plays a crucial role in neuropathic pain, ${ }^{[36]}$ and our research group provided evidence that it plays a crucial role in oxaliplatin-induced neuropathy. ${ }^{[37]}$ On these bases, we decided to interrogate the ability of the most potent FAAH inhibitors of this series to decrease OS. Accordingly, the efficacy of compounds $\mathbf{5 h}$ and $\mathbf{5 i}$, in comparison with our lead $\mathbf{3}$, was measured in a cellular acute model of OS induced by hy-

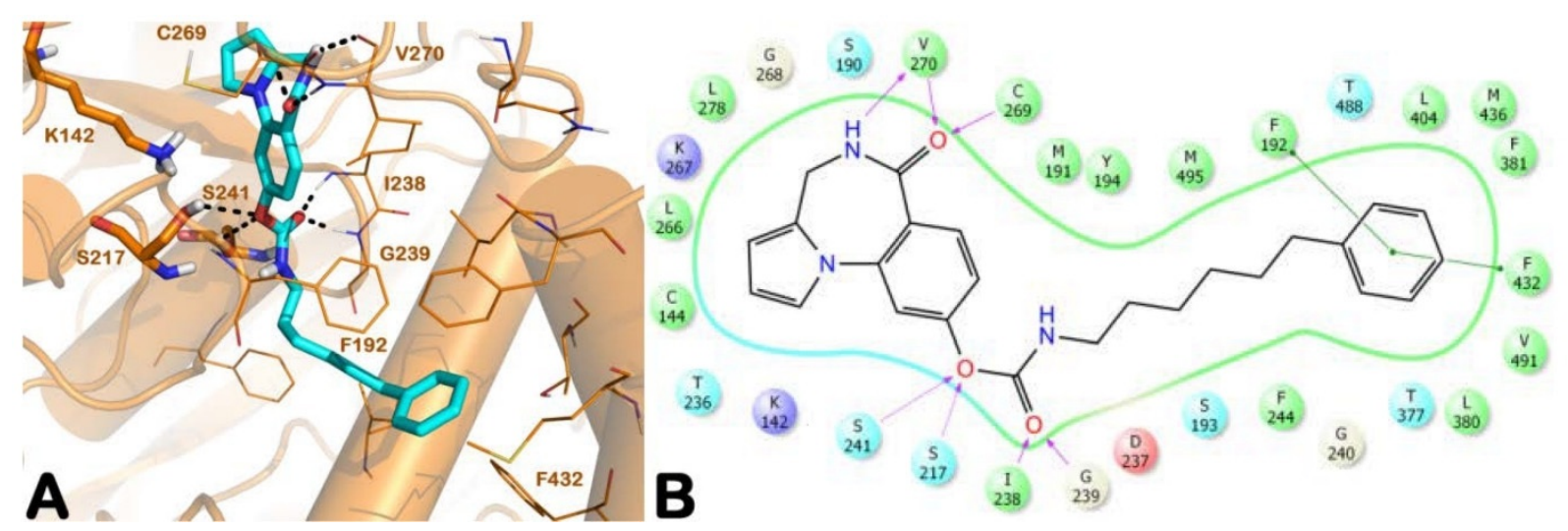

Figure 2. A) IFD pose and B) ligand interaction diagram of compound $\mathbf{5} \mathbf{h}$ (cyan sticks) in the FAAH enzyme (PDB ID: 3PPM in orange cartoon). The catalytic triad of the enzyme is represented by sticks, while the key residues of the FAAH binding site are represented by lines. Hydrogen bonds are represented by black dotted lines. Images were generated with PyMOL and Maestro (Maestro version 9.3, Schrödinger LLC, New York, NY, 2012). 


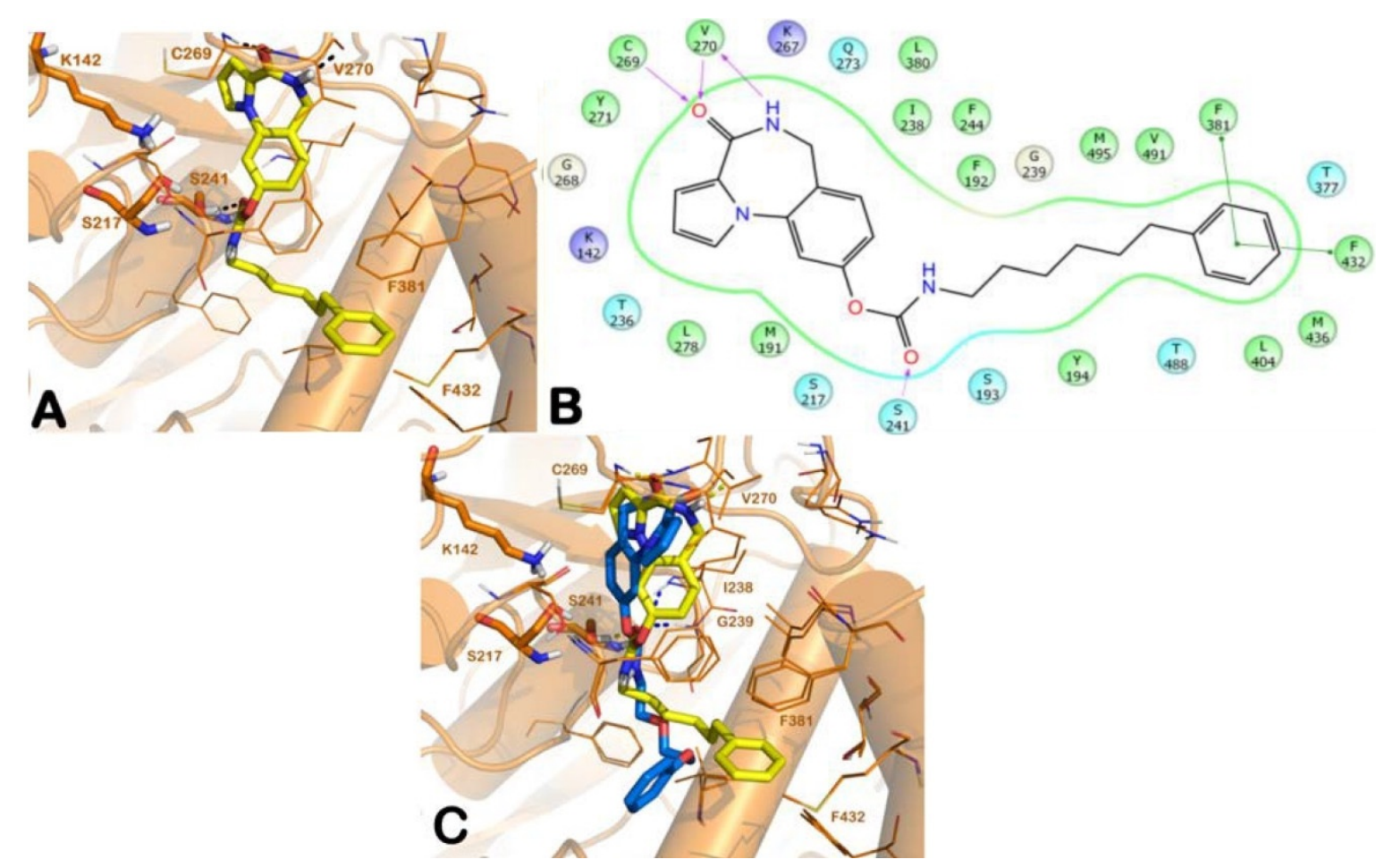

Figure 3. A) IFD pose and B) ligand interaction diagram of compound $\mathbf{5 i}$ (yellow sticks) in the FAAH enzyme (PDB ID: 3PPM in orange cartoon). C) Superposition between IFD poses of $\mathbf{5} \mathbf{i}$ (yellow sticks) and $\mathbf{5} \mathbf{j}$ (blue sticks). The catalytic triad of the enzyme is represented by sticks, while the key residues of the FAAH binding site are represented by lines. Hydrogen bonds are represented by dotted lines. Images were generated by PyMOL and Maestro (Maestro version 9.3, Schrödinger LLC, New York, NY, 2012).

drogen peroxide. By applying our previously described model, ${ }^{[38]}$ a preliminary test was performed to assess the effects of the tested compounds in the morphology of IMR32 cells. As outlined in Figure S7 of the SI, after treating the cells for $24 \mathrm{~h}$ with increasing concentrations (between 0.1 and $50 \mu \mathrm{M})$ of $\mathbf{3}, \mathbf{5} \mathbf{h}$, and $\mathbf{5 i}$, no changes were observed in cellular morphology.

We then tested the cytotoxicity profile in the same cell line by measuring the release of lactate dehydrogenase (LDH) in the media, as measured by enzymatic assay (see the SI for details). As positive control (LDH amount corresponding to $100 \%$ cell death) IMR32 cells were treated with $1 \%$ Triton X-100, according to the manufacturer's instructions (Roche, Mannheim, Germany). Notably, no significant cytotoxic effect was observed for all the tested compounds at concentrations ranging from 0.1 to $50 \mu \mathrm{M}$ (SI, Figure S8).

These results with $\mathbf{3}, \mathbf{5} \mathbf{h}$, and $\mathbf{5 i}$ prompted us to evaluate their potential anti-inflammatory and neuroprotective properties after treating the cells with pro-inflammatory substances. To find the most appropriate model for probing anti-inflammatory potential of our molecules in the IMR32 cell line we tested several pro-inflammatory mediators. We first evaluated the activation of NF- $\kappa B$ by measuring the translocation of its cytoplasmic subunit p65 to the nucleus. Accordingly, we treated the cells with lipopolysaccharide (LPS; $100 \mu \mathrm{g} \mathrm{mL}^{-1}$ and $200 \mu \mathrm{g} \mathrm{m}^{-1}$ ) for 30,60 , and $90 \mathrm{~min}$. The $100 \mu \mathrm{g}$ treatment after 30 min was the most effective, in which we could clearly observe the nuclear translocation of p65 protein (see SI Fig- ure S9: the increment of the LPS bar with respect to the control bar). Thus, according to our protocol, we pre-treated the cells with compounds $\mathbf{3}, \mathbf{5} \mathbf{h}$, and $\mathbf{5} \mathbf{i}$ for $24 \mathrm{~h}$ and subsequently with $100 \mu \mathrm{g} \mathrm{m}^{-1}$ LPS for $30 \mathrm{~min}$. As shown in SI Figure S9, the pre-treatment was able to decrease p65 translocation with respect to the cells treated with LPS alone. Notably, while $\mathbf{5 i}$ exerted its higher anti-inflammatory action at $1 \mu \mathrm{M}$, compound $\mathbf{5 h}$ exerted an anti-inflammatory effect inversely proportional to the dose.

\section{In vivo efficacy: effect of acute administration of com- pounds $3,5 \mathrm{~h}$, and $5 \mathrm{i}$ on oxaliplatin-induced neuropathic pain}

We evaluated the effect of compounds $3, \mathbf{5 h}$, and $\mathbf{5 i}$ in a mouse model of neuropathic pain, the chemotherapy-dependent neuropathy induced by oxaliplatin. ${ }^{[39-40]}$ The repeated administration of the neurotoxic anticancer agent $\left(2.4 \mathrm{mg} \mathrm{kg}^{-1}\right.$, i.p.) evoked an allodynia-like behavior measurable as increased sensitivity to a non-noxious cold stimulus (cold plate test). On day 14 , the licking latency decreased to $10.7 \pm 0.9 \mathrm{~s}$ in comparison $(P<0.01)$ to control mice $(20.1 \pm 0.8 \mathrm{~s})$ treated with vehicle (Figure 4). FAAH inhibitors were tested in oxaliplatin-treated animals on day 14 , and the pain relieving effects were evaluated over time after a single orally administered dose of the test compounds. We initially established that our potent and selective FAAH inhibitor $\mathbf{3}$ was able to dose-dependently increase the pain threshold at 3 and $10 \mathrm{mg} \mathrm{kg}^{-1}$, peaking $30 \mathrm{~min}$ after 

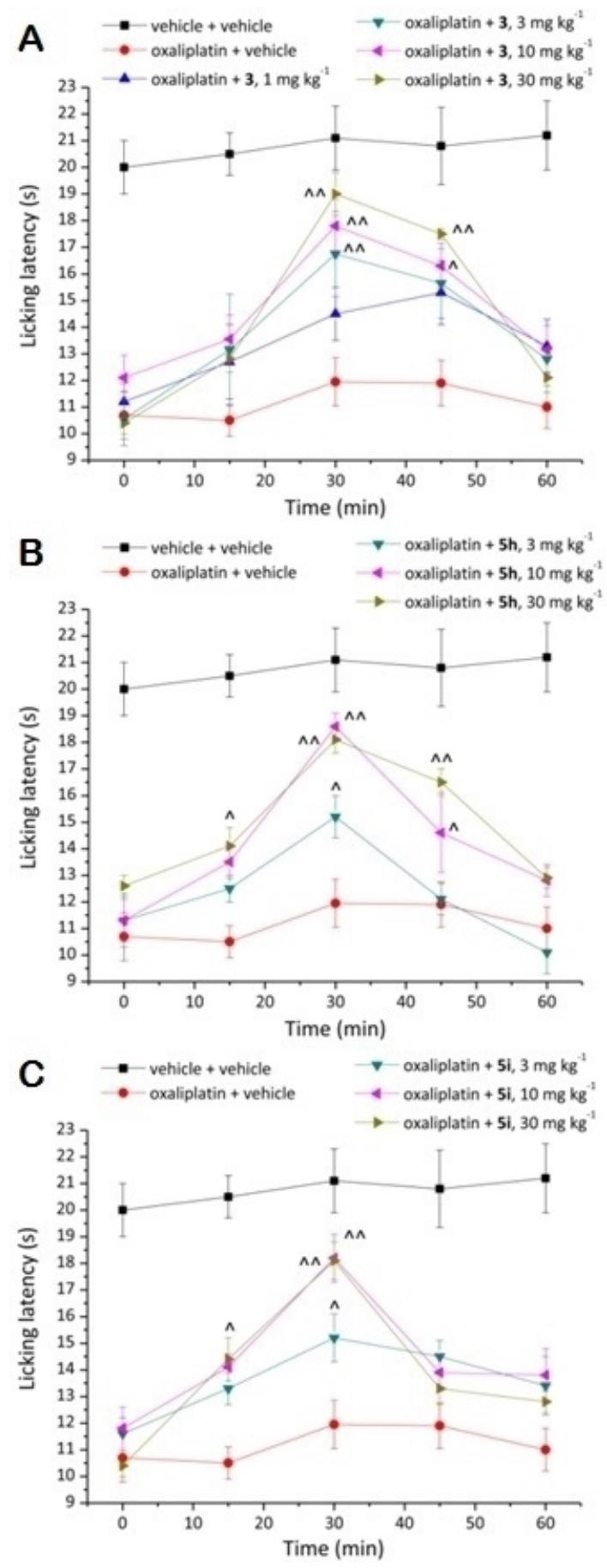

Figure 4. Pain relieving effect of compounds $\mathbf{3}, \mathbf{5 h}$, and $\mathbf{5 i}$. Mice were treated with oxaliplatin $\left(2.4 \mathrm{mg} \mathrm{kg}^{-1}\right.$ i.p. daily for five consecutive days every week for two weeks) to induce a painful neuropathy. Tested compounds were administered p.o. on day 14 , and control animals were treated with vehicles. Pain threshold was evaluated measuring the licking latency to a cold non-noxious stimulus (cold plate test). Each value represents the mean \pm SEM of 12 mice performed in two different experimental sets. $\triangle P<0.05$ and $\triangle \triangle P<0.01$ with respect to the value before treatment.

treatment. Based on this, we tested the analogues $\mathbf{5} \mathbf{h}$ and $\mathbf{5 i}$ (in a dose range of $3-30 \mathrm{mg} \mathrm{kg}^{-1}$ p.o.). As shown in Figure 4, both compounds induced a significant relief of oxaliplatin-induced neuropathic pain starting from $3 \mathrm{mg} \mathrm{kg}^{-1}$. Higher effects were obtained using $\mathbf{5} \mathbf{h}$ and $\mathbf{5 i}$, administered at doses of 10 and $30 \mathrm{mg} \mathrm{kg}^{-1}$. These dosages were equally effective between 15 and 30 min after administration. Compound $\mathbf{5} \mathbf{h}$ was significantly effective up to $45 \mathrm{~min}$ (Figure 4).

\section{Conclusions}

FAAH significantly contributes to the termination of EC signaling and is a relevant therapeutic target. By inhibition of the EC-metabolizing enzymes, one can attain indirect agonism at CBRs and therapeutic efficacy devoid of psychotropic effects. Aimed at the discovery of new selective FAAH inhibitors, herein we have described the development and SAR analysis of a series of new analogues $(5 \mathrm{a}-\mathrm{I})$ bearing functionalized tricyclic scaffolds and structurally inspired by our previous ligands 3 and 4 . The developed compounds showed an excellent selectivity profile for FAAH over $M A G L, C B_{1} R$, and $C B_{2} R$, with $5 \mathbf{i}$ showing some (micromolar) affinity at CBRs. The most potent FAAH inhibitors of the series $\mathbf{5} \mathbf{h}$ and $\mathbf{5} \mathbf{i}$ were used for further studies. In assays with a neuroblastoma cell line (IMR32) $\mathbf{5} \mathbf{h}, \mathbf{5 i}$, and our reference compound $\mathbf{3}$ demonstrated an absence of cytotoxic effects and the ability to reduce oxidative stress by decreasing the expression of the redox-sensitive transcription factor NF-кB. The efficacy of the same compounds was also assessed in vivo in a rodent model of neuropathic pain. After oral administration at $10 \mathrm{mg} \mathrm{kg}^{-1}$ all three compounds were able to relieve the hypersensitivity induced by oxaliplatin.

\section{Experimental Section}

\section{Chemistry}

Unless otherwise specified, materials were purchased from commercial suppliers and used without further purification. Reaction progress was monitored by TLC using silica gel $60 \mathrm{~F}_{254}(0.040-$ $0.063 \mathrm{~mm}$ ) with detection by UV. Silica gel $60(0.040-0.063 \mathrm{~mm})$ was used for column chromatography. ${ }^{1} \mathrm{H}$ and ${ }^{13} \mathrm{C}$ NMR spectra were recorded on a Varian $300 \mathrm{MHz}$ spectrometer or a Bruker $400 \mathrm{MHz}$ spectrometer by using the residual signal of the deuterated solvent as internal standard. Splitting patterns are described as singlet (s), doublet (d), triplet (t), quartet (q), and broad (br); chemical shift values $(\delta)$ are given in ppm and coupling constants $(J)$ in Hertz $(\mathrm{Hz})$. Microwave reactions were performed with a CEM Discovery apparatus. ESI-MS spectra were performed with an Agilent 1100 Series LC/MSD spectrometer. High-resolution (HR) ESI-MS data were collected on a Thermo Finningan LCQ Deca XP Max ion-trap mass spectrometer equipped with Xcalibur software, operating in positive ion mode. The yields refer to purified products and are not optimized. All moisture-sensitive reactions were performed under an argon atmosphere using oven-dried glassware and anhydrous solvents. Final compounds were analyzed by combustion analysis $(\mathrm{C}, \mathrm{H}, \mathrm{N})$ to confirm purity $>95 \%$.

$N$-Phenyl-4-(pyrrolo[1,2-a]quinoxalin-4-yl)piperazine-1-carboxamide (5a): Compound 6 (60 mg, $0.24 \mathrm{mmol}$ ) was dissolved in dry THF $(2.0 \mathrm{~mL})$ and TEA $(33 \mu \mathrm{L}, 0.24 \mathrm{mmol})$ was added. Then phenyl isocyanate ( $7 \mathrm{a})(52 \mu \mathrm{L}, 0.47 \mathrm{mmol})$ was added dropwise and the reaction mixture was heated at reflux for $12 \mathrm{~h}$. After reaction completion volatiles were removed in vacuo and the residue was purified. Column chromatography on silica gel ( $n$-hexane/EtOAc 2:1) provid- 
ed pure title compound ( $62 \%$ yield) as a pale-yellow solid. ${ }^{1} \mathrm{H}$ NMR $\left(300 \mathrm{MHz}, \mathrm{CDCl}_{3}\right): \delta=3.74(\mathrm{~m}, 4 \mathrm{H}), 3.91(\mathrm{~m}, 4 \mathrm{H}), 6.45$ (brs, $\left.1 \mathrm{H}\right)$, $6.79(\mathrm{~m}, 2 \mathrm{H}), 7.06(\mathrm{~m}, 2 \mathrm{H}), 7.26-7.41(\mathrm{~m}, 5 \mathrm{H}), 7.67-7.76(\mathrm{~m}, 2 \mathrm{H})$, $7.85 \mathrm{ppm}(\mathrm{m}, 1 \mathrm{H}) ;{ }^{13} \mathrm{C} \mathrm{NMR}\left(75 \mathrm{MHz}, \mathrm{CDCl}_{3}\right): \delta=43.7,47.5,106.7$, $112.6,113.3,114.6,120.0$ (2C), 123.3 (2C), 124.3, 125.2, 125.8, 127.5, 128.9 (2C), 152.3, 155.0 ppm; ESI-MS m/z $372[\mathrm{M}+\mathrm{H}]^{+}(100), 394$ $[M+\mathrm{Na}]^{+}$; Elemental analysis calcd (\%) for $\mathrm{C}_{22} \mathrm{H}_{21} \mathrm{~N}_{5} \mathrm{O}: \mathrm{C} 71.14, \mathrm{H}$ 5.70, N 18.85, found: C 71.08, H 5.93, N1 8.70.

$N$-(6-Phenylhexyl)-4-(pyrrolo[1,2-a]quinoxalin-4-yl)piperazine-1carboxamide ( $5 \mathrm{~b}$ ): The title compound was prepared according to the procedure previously described for $5 \mathrm{a}$ starting from $\mathbf{6}(100 \mathrm{mg}$, $0.40 \mathrm{mmol})$, TEA $(56 \mu \mathrm{L}, 0.40 \mathrm{mmol}$ ) and 6-phenyl-1-hexylisocyanate (7 b) (161 mg, $0.79 \mathrm{mmol})$. Column chromatography on silica gel ( $n$-hexane/EtOAc 1:1) provided pure title compound (59\% yield) as a pale-yellow amorphous solid. ${ }^{1} \mathrm{H}$ NMR $\left(300 \mathrm{MHz}, \mathrm{CDCl}_{3}\right): \delta=1.28-$ $1.67(\mathrm{~m}, 8 \mathrm{H}), 2.62(\mathrm{t}, J=7.8 \mathrm{~Hz}, 2 \mathrm{H}), 3.26(\mathrm{~m}, 2 \mathrm{H}), 3.59(\mathrm{~m}, 4 \mathrm{H})$, $3.84(\mathrm{~m}, 4 \mathrm{H}), 4.64(\mathrm{brt}, 1 \mathrm{H}), 6.77(\mathrm{~m}, 2 \mathrm{H}), 7.15-7.36(\mathrm{~m}, 7 \mathrm{H}), 7.68$ $(\mathrm{m}, 2 \mathrm{H}), 7.82 \mathrm{ppm}(\mathrm{m}, 1 \mathrm{H})$; ESI-MS $\mathrm{m} / \mathrm{z} 456[\mathrm{M}+\mathrm{H}]^{+}$, (100) 478 $[\mathrm{M}+\mathrm{Na}]^{+}$; Elemental analysis calcd (\%) for $\mathrm{C}_{28} \mathrm{H}_{33} \mathrm{~N}_{5} \mathrm{O}: \mathrm{C} 73.82, \mathrm{H}$ 7.30, N 15.37, found: C 73.75, H 7.51, N 15.71 .

$N$-(Undec-10-yn-1-yl)-4-(pyrrolo[1,2-a]quinoxalin-4-yl)piperazine1 -carboxamide $(5 \mathrm{c})$ : The title compound was prepared according to the procedure described for $5 \mathrm{a}$ starting from $6(72 \mathrm{mg}$ $0.29 \mathrm{mmol})$, TEA $(40 \mu \mathrm{L}, 0.29 \mathrm{mmol})$ and undec-10-yn-1-yl isocyanate $(7 \mathrm{c})(110 \mathrm{mg}, 0.57 \mathrm{mmol})$. Column chromatography on silica gel ( $n$-hexane/EtOAc 2:1) provided pure title compound $(60 \%$ yield) as a pale-yellow amorphous solid. ${ }^{1} \mathrm{H}$ NMR $\left(300 \mathrm{MHz}, \mathrm{CDCl}_{3}\right)$ : $\delta=1.23-1.54(\mathrm{~m}, 14 \mathrm{H}), 1.94(\mathrm{~m}, 1 \mathrm{H}), 2.18(\mathrm{~m}, 2 \mathrm{H}), 3.26(\mathrm{~m}, 2 \mathrm{H})$, $3.60(\mathrm{~m}, 4 \mathrm{H}), 3.84(\mathrm{~m}, 4 \mathrm{H}), 4.53(\mathrm{brt}, 1 \mathrm{H}), 6.78(\mathrm{~m}, 2 \mathrm{H}), 7.26-7.32$ $(\mathrm{m}, 2 \mathrm{H}), 7.64-7.74(\mathrm{~m}, 2 \mathrm{H}), 7.83 \mathrm{ppm}(\mathrm{s}, 1 \mathrm{H})$; ESI-MS m/z $446[\mathrm{M}+$ $\mathrm{H}^{+}$, (100) $468[\mathrm{M}+\mathrm{Na}]^{+}$; Elemental analysis calcd (\%) for $\mathrm{C}_{27} \mathrm{H}_{35} \mathrm{~N}_{5} \mathrm{O}: \mathrm{C} 72.78, \mathrm{H}$ 7.92, N 15.72, found: C 72.73, H 8.14, N 16.03 .

\section{4-(4-(6-Phenylhexyl)piperazin-1-yl)pyrrolo[1,2-a]quinoxaline}

(5 d): 6-Phenylhexylbromide ( $96 \mathrm{mg}, 0.40 \mathrm{mmol}$ ) was dissolved in MeCN (HPLC grade, $4.0 \mathrm{~mL}$ ) and the solution was heated at reflux. Then, compound $6(100 \mathrm{mg}, 0.40 \mathrm{mmol})$ was added, followed by TEA $(61 \mu \mathrm{L}, 0.44 \mathrm{mmol})$. The reaction mixture was heated at reflux for $12 \mathrm{~h}$ and the volatiles were evaporated in vacuo. Column chromatography on silica gel ( $n$-hexane/EtOAc 2:1) provided pure title compound $\left(75 \%\right.$ yield) as a pale-yellow oil. ${ }^{1} \mathrm{H} N M R(300 \mathrm{MHz}$, $\left.\mathrm{CDCl}_{3}\right): \delta=1.39-1.69(\mathrm{~m}, 8 \mathrm{H}), 2.42(\mathrm{~m}, 2 \mathrm{H}), 2.64(\mathrm{~m}, 6 \mathrm{H}), 3.85(\mathrm{~m}$, $4 \mathrm{H}), 6.78(\mathrm{~m}, 2 \mathrm{H}), 7.19-7.30(\mathrm{~m}, 7 \mathrm{H}), 7.72(\mathrm{~m}, 2 \mathrm{H}), 7.81 \mathrm{ppm}(\mathrm{m}$, $1 \mathrm{H}) ;{ }^{13} \mathrm{C}$ NMR $\left(75 \mathrm{MHz}, \mathrm{CDCl}_{3}\right): \delta=22.8,23.5,25.3,25.3,27.5,32.0$, 44.0 (2), 49.4 (2), 54.9, 102.8, 108.4, 109.3, 110.4, 116.3, 119.9, 121.2, 121.6, 121.8, 123.5, 124.3 (2C), 124.4 (2C), 132.3, 138.8, 148.6 ppm; ESI-MS $m / z 413[M+H]^{+}$; Elemental analysis calcd (\%) for $\mathrm{C}_{27} \mathrm{H}_{32} \mathrm{~N}_{4}$ : C 78.60, H 7.82, N 13.58, found: C 78.87, H 7.68, N 13.35 .

\section{4-(4-(Undec-10-yn-1-yl)piperazin-1-yl)pyrrolo[1,2-a]quinoxaline}

(5e): The title compound was prepared according to the procedure described for $\mathbf{5} \mathbf{d}$ starting from 6 (55 $\mathrm{mg}, 0.22 \mathrm{mmol}$ ), undec10-yn-1-yl bromide (50 mg, $0.22 \mathrm{mmol})$ and TEA $(33 \mu \mathrm{L}$, $0.24 \mathrm{mmol})$. Column chromatography on silica gel ( $n$-hexane/EtOAc $2: 1)$ provided pure title compound ( $71 \%$ yield) as a pale-yellow oil. ${ }^{1} \mathrm{H}$ NMR $\left(300 \mathrm{MHz}, \mathrm{CDCl}_{3}\right): \delta=1.26-1.56(\mathrm{~m}, 14 \mathrm{H}), 1.94(\mathrm{~m}, 1 \mathrm{H})$, $2.20(\mathrm{~m}, 2 \mathrm{H}), 2.41(\mathrm{~m}, 2 \mathrm{H}), 2.64(\mathrm{~m}, 4 \mathrm{H}), 3.84(\mathrm{~m}, 4 \mathrm{H}), 6.76(\mathrm{~m}, 2 \mathrm{H})$, $7.22-7.35(\mathrm{~m}, 2 \mathrm{H}), 7.67(\mathrm{~m}, 2 \mathrm{H}), 7.81 \mathrm{ppm}(\mathrm{m}, 1 \mathrm{H})$; ESI-MS m/z 403 $[\mathrm{M}+\mathrm{H}]^{+}$; Elemental analysis calcd (\%) for $\mathrm{C}_{26} \mathrm{H}_{34} \mathrm{~N}_{4}$ : C 77.57, $\mathrm{H}$ 8.51, N 13.92, found C 77.73, H 8.38, N 14.09.

tert-Butyl 3-methoxy-2-nitrophenylcarbamate (9): To a solution of 3-methoxy-2-nitrobenzoic acid (8) $(1 \mathrm{~g}, 5.08 \mathrm{mmol})$ in $20.0 \mathrm{~mL}$ of tert-butanol were added diphenylphosphoryl azide $(1.15 \mathrm{~mL}$, $5.36 \mathrm{mmol})$ and TEA $(0.75 \mathrm{~mL}, 5.42 \mathrm{mmol})$. The reaction mixture was heated at reflux for $15 \mathrm{~h}$, then cooled to $25^{\circ} \mathrm{C}$ and solvents were removed by rotary evaporation. Residue was taken up with EtOAc and washed with a saturated aqueous solution of $\mathrm{NH}_{4} \mathrm{Cl}$, water, a saturated solution of $\mathrm{NaHCO}_{3}$ and brine. The organic layer was dried over anhydrous $\mathrm{Na}_{2} \mathrm{SO}_{4}$, filtered and concentrated affording the title compound (78\% yield). ${ }^{1} \mathrm{H} \mathrm{NMR}\left(300 \mathrm{MHz}, \mathrm{CDCl}_{3}\right): \delta=$ $1.38(\mathrm{~s}, 9 \mathrm{H}), 3.83(\mathrm{~s}, 3 \mathrm{H}), 6.68(\mathrm{dd}, J=7.5,1.5 \mathrm{~Hz}, 1 \mathrm{H}), 7.71(\mathrm{t}, J=$ $7.5 \mathrm{~Hz}, 1 \mathrm{H}), 8.09$ (dd, $J=7.5,1.5 \mathrm{~Hz}, 1 \mathrm{H}), 9.15 \mathrm{ppm}$ (brs, 1H); ESIMS $m / z 291[M+N a]^{+}(100)$.

3-Methoxy-2-nitroaniline (10): Compound 9 (1.2 g, $4.47 \mathrm{mmol})$ was dissolved in $1.4 \mathrm{~mL}$ of TFA and the resulting solution was stirred at $0^{\circ} \mathrm{C}$ for $1.5 \mathrm{~h}$. Then the solvent was evaporated and the residue was dissolved in EtOAc and washed with a saturated aqueous $\mathrm{NaHCO}_{3}$. The organic phase was dried over anhydrous $\mathrm{Na}_{2} \mathrm{SO}_{4}$ filtered and concentrated affording the title compound (99\% yield). ${ }^{1} \mathrm{H}$ NMR (300 MHz, $\left.\mathrm{CDCl}_{3}\right): \delta=3.87(\mathrm{~s}, 3 \mathrm{H}), 4.43$ (brs, $2 \mathrm{H}$ ), $6.30(\mathrm{dd}, J=8.2,0.9 \mathrm{~Hz}, 1 \mathrm{H}), 6.36(\mathrm{dd}, J=7.5,1.5 \mathrm{~Hz}, 1 \mathrm{H}), 7.16 \mathrm{ppm}$ $(\mathrm{t}, J=8.2 \mathrm{~Hz}, 1 \mathrm{H})$; ESI-MS m/z $169[\mathrm{M}+\mathrm{H}]^{+}$.

1-(3-Methoxy-2-nitrophenyl)-1H-pyrrole (11): To a solution of 3methoxy-2-nitroaniline $10(500 \mathrm{mg}, 2.97 \mathrm{mmol})$ in acetic acid $(10.0 \mathrm{~mL})$ and water $(2.0 \mathrm{~mL}), 2,5$-dimethoxytetrahydrofuran (385 $\mu \mathrm{L}, 2.97 \mathrm{mmol})$ in acetic acid $(1.0 \mathrm{~mL})$ was added dropwise. The solution was heated at $100^{\circ} \mathrm{C}$ for $15 \mathrm{~min}$. After removal of the solvent, the dark-brown reaction mixture was diluted with EtOAc and neutralized with an aqueous saturated solution of $\mathrm{Na}_{2} \mathrm{CO}_{3}$. Then, it was extracted with EtOAc $(3 \times 100 \mathrm{~mL})$, dried over anhydrous $\mathrm{Na}_{2} \mathrm{SO}_{4}$, filtered, and concentrated. Compound 11 (97\% yield) was obtained as a colorless solid. ${ }^{1} \mathrm{H}$ NMR $\left(300 \mathrm{MHz}, \mathrm{CDCl}_{3}\right)$ : $\delta=3.83(\mathrm{~s}, 3 \mathrm{H}), 6.41(\mathrm{~d}, J=1.5 \mathrm{~Hz}, 2 \mathrm{H}), 6.94(\mathrm{dd}, J=7.5,1.5 \mathrm{~Hz}$, $1 \mathrm{H}), 7.26(\mathrm{~d}, J=1.5 \mathrm{~Hz}, 2 \mathrm{H}), 7.44(\mathrm{dd}, J=7.5,1.5 \mathrm{~Hz}, 1 \mathrm{H}), 7.73 \mathrm{ppm}$ $(\mathrm{t}, J=8.2 \mathrm{~Hz}, 1 \mathrm{H})$; ESI-MS $\mathrm{m} / \mathrm{z} 219[\mathrm{M}+\mathrm{H}]^{+}$.

2-Methoxy-6-(1H-pyrrol-1-yl)aniline (12): To a solution of 1-(3-methoxy-2-nitrophenyl)-1 $\mathrm{H}$-pyrrole (11) $(680 \mathrm{mg}, 3.12 \mathrm{mmol})$ in $75 \%$ $\mathrm{EtOH}(8.0 \mathrm{~mL}), \mathrm{CaCl}_{2}(229 \mathrm{mg}, 1.56 \mathrm{mmol})$ and iron powder $(1.23 \mathrm{~g}$, $7.09 \mathrm{mmol}$ ) were added. The reaction mixture was heated at reflux for $2 \mathrm{~h}$, then was filtered through a Celite pad. The solvent was removed and the residue was dissolved in $\mathrm{CHCl}_{3}$ and washed with water. The organic phase was dried over anhydrous $\mathrm{Na}_{2} \mathrm{SO}_{4}$, filtered and concentrated. The compound was submitted to the subsequent step without further purification ( $87 \%$ yield). ${ }^{1} \mathrm{H} N \mathrm{NR}$ (300 MHz, $\left.\mathrm{CDCl}_{3}\right): \delta=3.83(\mathrm{~s}, 3 \mathrm{H}), 6.27$ (brs, $\left.2 \mathrm{H}\right), 6.41(\mathrm{~d}, J=1.5 \mathrm{~Hz}$, $2 \mathrm{H}), 6.70(\mathrm{t}, J=8.2 \mathrm{~Hz}, 1 \mathrm{H}), 6.85(\mathrm{dd}, J=7.5,1.5 \mathrm{~Hz}, 1 \mathrm{H}), 6.93(\mathrm{dd}$, $J=7.5,1.5 \mathrm{~Hz}, 1 \mathrm{H}), 7.26 \mathrm{ppm}(\mathrm{d}, J=1.5 \mathrm{~Hz}, 2 \mathrm{H})$; ESI-MS $\mathrm{m} / \mathrm{z} 189$ $[\mathrm{M}+\mathrm{H}]^{+}$.

6-Methoxypyrrolo[1,2-a]quinoxalin-4(5H)-one (13): To a solution of $12(1.83 \mathrm{~g}, 9.73 \mathrm{mmol})$ in toluene $(26.0 \mathrm{~mL})$, triphosgene $(778 \mathrm{mg}, 2.63 \mathrm{mmol}$ ) was added and the resulting solution was heated at reflux for $2 \mathrm{~h}$. Then the reaction mixture was cooled under nitrogen flow and the solvent was evaporated. The residue was purified by silica gel column chromatography $\left(\mathrm{CHCl}_{3} / \mathrm{EtOAC}\right.$ $2: 1)$ affording the title compound (52\% yield) as colorless solid. ${ }^{1} \mathrm{H}$ NMR $\left(300 \mathrm{MHz}, \mathrm{CDCl}_{3}\right)$ : $\delta=3.97(\mathrm{~s}, 3 \mathrm{H}), 6.67-6.69(\mathrm{~m}, 1 \mathrm{H}), 6.81$ $(\mathrm{dd}, J=8.2,0.9 \mathrm{~Hz}, 1 \mathrm{H}), 7.14(\mathrm{t}, J=8.2 \mathrm{~Hz}, 1 \mathrm{H}), 7.25-7.28(\mathrm{~m}, 2 \mathrm{H})$, 7.64-7.65 (m, 1 H), 8.42 ppm (brs, 1 H); ESI-MS m/z $215[M+H]^{+}$.

6-Hydroxypyrrolo[1,2-a]quinoxalin-4(5H)-one (14): To a suspension of 6-methoxypyrrolo[1,2-a]quinoxalin-4(5H)-one (13) (100 mg, $0.47 \mathrm{mmol}$ ) in dry $\mathrm{CH}_{2} \mathrm{Cl}_{2}(6.0 \mathrm{~mL})$, boron tribromide ( $1 \mathrm{M}$ solution in $\mathrm{CH}_{2} \mathrm{Cl}_{2}, 1.87 \mathrm{~mL}, 1.87 \mathrm{mmol}$ ) was added at $-78^{\circ} \mathrm{C}$. The reaction mixture was then allowed to warm to room temperature and 
stirred for $12 \mathrm{~h}$. A saturated aqueous solution of $\mathrm{Na}_{2} \mathrm{CO}_{3}$ was added to quench the reaction. The residue was extracted with EtOAc ( $3 \times$ $20 \mathrm{~mL}$ ). The combined organic extracts were dried over anhydrous $\mathrm{Na}_{2} \mathrm{SO}_{4}$, filtered, and concentrated. Column chromatography $\left(\mathrm{CHCl}_{3} / \mathrm{EtOAC} 1: 1\right)$ provided the title compound (11\% yield) as a colorless solid. ${ }^{1} \mathrm{H}$ NMR $\left(300 \mathrm{MHz}, \mathrm{CD}_{3} \mathrm{OD}\right): \delta=6.68-6.70(\mathrm{~m}, 1 \mathrm{H})$, $6.79(\mathrm{~d}, J=8.2 \mathrm{~Hz}, 1 \mathrm{H}), 7.07(\mathrm{t}, J=8.2 \mathrm{~Hz}, 1 \mathrm{H}), 7.18(\mathrm{~d}, J=2.9 \mathrm{~Hz}$, $1 \mathrm{H}), 7.34(\mathrm{~d}, J=8.2 \mathrm{~Hz}, 1 \mathrm{H}), 7.92 \mathrm{ppm}(\mathrm{s}, 1 \mathrm{H}) ;$ ESI-MS $\mathrm{m} / \mathrm{z} 199$ $[\mathrm{M}-\mathrm{H}]^{-}$.

4-0xo-4,5-dihydropyrrolo[1,2-a]quinoxalin-6-yl 6-phenylhexylcarbamate $(5 \mathrm{f})$ : The title compound was prepared according to the procedure described for $\mathbf{5}$ a starting from 6-hydroxypyrrolo[1,2a]quinoxalin-4(5H)-one 14 (10 mg, $0.05 \mathrm{mmol})$, phenylhexyl isocyanate $7 \mathrm{~b}(41 \mathrm{mg}, 0.20 \mathrm{mmol})$ and TEA $(28 \mu \mathrm{L}, 0.20 \mathrm{mmol})$. Column chromatography $\left(\mathrm{CHCl}_{3}\right)$ afforded the title compound (30\% yield) as a colorless solid. ${ }^{1} \mathrm{H}$ NMR $\left(300 \mathrm{MHz}, \mathrm{CDCl}_{3}\right): \delta=1.36(\mathrm{~m}, 4 \mathrm{H}), 1.57$ $(\mathrm{m}, 4 \mathrm{H}), 2.55(\mathrm{t}, J=7.5 \mathrm{~Hz}, 2 \mathrm{H}), 3.31(\mathrm{t}, J=5.9 \mathrm{~Hz}, 2 \mathrm{H}), 6.70(\mathrm{~d}, J=$ $2.3 \mathrm{~Hz}, 1 \mathrm{H}), 7.11-7.26(\mathrm{~m}, 7 \mathrm{H}), 7.46(\mathrm{~d}, J=8.5 \mathrm{~Hz}, 1 \mathrm{H}), 7.61(\mathrm{~d}, J=$ $8.2 \mathrm{~Hz}, 1 \mathrm{H}), 7.70(\mathrm{~s}, 1 \mathrm{H}), 10.95 \mathrm{ppm}(\mathrm{s}, 1 \mathrm{H}) ;{ }^{13} \mathrm{C}$ NMR $(75 \mathrm{MHz}$, $\left.\mathrm{CDCl}_{3}\right): \delta=26.9,29.1,30.1,31.5,36.1,41.6,110.3,112.4,113.7$, $117.8,118.7,120.8,123.0,124.2,125.5,125.8,128.5$ (2), 128.6 (2), 139.7, 142.9, 153.6, 156.7 ppm; ESI-MS m/z $426[\mathrm{M}+\mathrm{Na}]^{+}$; Elemental analysis calcd (\%) for $\mathrm{C}_{24} \mathrm{H}_{25} \mathrm{~N}_{3} \mathrm{O}_{3}: \mathrm{C} 71.44, \mathrm{H}$ 6.25, N 10.41, found: C 71.76, H 6.09, N 10.27.

$\mathbf{N}$-(5-Hydroxy-2-nitrophenyl)acetamide (16): To a solution of 15 $(1.0 \mathrm{~g}, 6.62 \mathrm{mmol})$ in acetic anhydride $(5.0 \mathrm{~mL})$, a mixture of conc. $\mathrm{HNO}_{3}(3.6 \mathrm{~mL})$ and acetic acid $(3.6 \mathrm{~mL})$ was added and the reaction was stirred at $25^{\circ} \mathrm{C}$ for $8 \mathrm{~h}$. $\mathrm{HCl}(2 \mathrm{~N}, 5.0 \mathrm{~mL})$ was added to quench the excess of acetic anhydride and the mixture was diluted with water. The resulting precipitate was filtered and washed with cold water to afford the pure title compound ( $98 \%$ yield) as a yellow solid. ${ }^{1} \mathrm{H}$ NMR $\left(300 \mathrm{MHz}, \mathrm{CDCl}_{3}\right): \delta=2.24(\mathrm{~s}, 3 \mathrm{H}), 7.07(\mathrm{~d}, J=7.6 \mathrm{~Hz}$, $1 \mathrm{H}), 7.35$ (brs, $1 \mathrm{H}), 7.46(\mathrm{~s}, 1 \mathrm{H}), 8.07(\mathrm{~d}, J=9.4 \mathrm{~Hz}, 1 \mathrm{H}), 10.82 \mathrm{ppm}$ $(\mathrm{s}, 1 \mathrm{H})$; ESI-MS m/z $195[\mathrm{M}-\mathrm{H}]^{-}$.

4-Amino-3-(1H-pyrrol-1-yl)phenol (17): Compound 16 (1.2 g, $6.49 \mathrm{mmol})$ was dissolved in concentrated $\mathrm{HCl}(10.0 \mathrm{~mL})$ and the resulting suspension was stirred at $110^{\circ} \mathrm{C}$ for $5 \mathrm{~min}$. The mixture was cooled to $25^{\circ} \mathrm{C}$, diluted with water and the aqueous phase was extracted with EtOAc $(3 \times 15.0 \mathrm{~mL})$. The combined organic layers were dried over $\mathrm{Na}_{2} \mathrm{SO}_{4}$, filtered, and concentrated to afford the intermediate 3-amino-4-nitrophenol (95\% yield) that was carried on without any further purification. ${ }^{1} \mathrm{H} \mathrm{NMR}(300 \mathrm{MHz}$, [D $\mathrm{D}_{6}$ ]acetone): $\delta=6.24$ (dd, $\left.J=9.4,2.6 \mathrm{~Hz}, 1 \mathrm{H}\right), 6.45(\mathrm{~d}, J=2.4 \mathrm{~Hz}$, $1 \mathrm{H}), 7.01$ (brs, 2H), $7.97(\mathrm{~d}, J=9.4 \mathrm{~Hz}, 1 \mathrm{H}), 9.37 \mathrm{ppm}(\mathrm{s}, 1 \mathrm{H})$; ESIMS $\mathrm{m} / \mathrm{z} 153[\mathrm{M}-\mathrm{H}]^{-}$.

A stirred solution of 3-amino-4-nitrophenol (950 mg, $6.17 \mathrm{mmol}$ ) and 2,5-dimethoxytetrahydrofuran $(960 \mu \mathrm{L}, 7.41 \mathrm{mmol})$ in 1,4-dioxane $(20.0 \mathrm{~mL})$, was stirred at $120^{\circ} \mathrm{C}$ for 15 min before adding $5 \mathrm{~N}$ $\mathrm{HCl}(1.5 \mathrm{~mL})$. The mixture was stirred at $110^{\circ} \mathrm{C}$ for further $5 \mathrm{~min}$, then cold water was added and the resulting white precipitate was filtered and washed with cold water to afford the pure 4-nitro-3(1 $\mathrm{H}$-pyrrol-1-yl)phenol $\left(70 \%\right.$ yield) as an amorphous solid. ${ }^{1} \mathrm{H}$ NMR $\left(300 \mathrm{MHz}, \mathrm{CDCl}_{3}\right): \delta=6.36(\mathrm{~d}, J=1.5 \mathrm{~Hz}, 2 \mathrm{H}), 6.79(\mathrm{~d}, J=1.5 \mathrm{~Hz}$, $2 \mathrm{H}), 6.85(\mathrm{~s}, 1 \mathrm{H}), 7.17(\mathrm{~d}, J=2.6 \mathrm{~Hz}, 1 \mathrm{H}), 7.92 \mathrm{ppm}(\mathrm{d}, J=8.5 \mathrm{~Hz})$; ESI-MS m/z $203[\mathrm{M}-\mathrm{H}]^{-}$.

To a solution of 4-nitro-3-(1H-pyrrol-1-yl)phenol (400 mg, $1.96 \mathrm{mmol})$ in EtOAC $(10.0 \mathrm{~mL}) \mathrm{SnCl}_{2} \cdot 2 \mathrm{H}_{2} \mathrm{O}(2.2 \mathrm{~g}, 9.8 \mathrm{mmol})$ was added and the reaction was stirred at $25^{\circ} \mathrm{C}$ for $2 \mathrm{~h}$. A saturated solution of $\mathrm{NaHCO}_{3}$ was added and the aqueous phase was extracted with EtOAc $(3 \times 20.0 \mathrm{~mL})$. The combined organic layers were dried over $\mathrm{Na}_{2} \mathrm{SO}_{4}$, filtered and evaporated. The crude was purified by means of chromatography on silica gel (petroleum ether/ $\mathrm{Et}_{2} \mathrm{O} 3: 2$ ) to give pure compound 17 (85\% yield) as a colorless solid. ${ }^{1} \mathrm{H}$ NMR $\left(300 \mathrm{MHz}, \mathrm{CDCl}_{3}\right): \delta=4.09$ (brs, $\left.2 \mathrm{H}\right), 6.33(\mathrm{~s}, 2 \mathrm{H}), 6.62-6.67(\mathrm{~m}, 3 \mathrm{H})$, $7.80(\mathrm{~s}, 2 \mathrm{H}), 7.16 \mathrm{ppm}(\mathrm{s}, 1 \mathrm{H})$; ESI-MS m/z $175[\mathrm{M}+\mathrm{H}]^{+}$.

8-Hydroxypyrrolo[1,2-a]quinoxalin-4(5H)-one (18): Starting from $17(100 \mathrm{mg}, 0.57 \mathrm{mmol})$, the title compound was obtained following the same procedure reported for 13 . The crude was purified by means of chromatography on silica gel $\left(\mathrm{MeOH} / \mathrm{CHCl}_{3} 1: 20\right)$ to provide title compound ( $36 \%$ yield) as a colorless solid. ${ }^{1} \mathrm{H}$ NMR (300 MHz, [D 6 DMSO): $\delta=6.63(\mathrm{~m}, 1 \mathrm{H}), 6.73-6.76(\mathrm{~m}, 1 \mathrm{H}), 6.70(\mathrm{~m}$, $1 \mathrm{H}), 7.09-7.12(\mathrm{~m}, 1 \mathrm{H}), 7.36(\mathrm{~s}, 1 \mathrm{H}), 8.01(\mathrm{~m} 1 \mathrm{H}), 9.57(\mathrm{~s}, 1 \mathrm{H})$, $11.00 \mathrm{ppm}(\mathrm{s}, 1 \mathrm{H})$; ESI-MS m/z $199[\mathrm{M}-\mathrm{H}]^{-}$.

4-Oxo-4,5-dihydropyrrolo[1,2-a]quinoxalin-8-yl 6-phenylhexylcarbamate $(5 \mathrm{~g})$ : Starting from $18(40 \mathrm{mg}, 0.20 \mathrm{mmol})$ and 6-phenylhexyl isocyanate $(165 \mathrm{mg}, 0.80 \mathrm{mmol})$, the title compound was obtained following the same procedure reported for $5 \mathrm{a}$. The crude was purified by means of chromatography on silica gel $\left(\mathrm{Et}_{2} \mathrm{O} / \mathrm{CHCl}_{3}\right.$ $2: 1)$ to afford title compound ( $10 \%$ yield) as a colorless solid. ${ }^{1} \mathrm{H}$ NMR (300 MHz, CD $\left.\mathrm{OD}\right): \delta=1.39-1.42(\mathrm{~m}, 4 \mathrm{H}), 1.55-1.67(\mathrm{~m}$, $4 \mathrm{H}), 2.58(\mathrm{t}, J=7.5 \mathrm{~Hz}, 2 \mathrm{H}), 3.18(\mathrm{t}, J=7.0 \mathrm{~Hz}, 2 \mathrm{H}), 6.69-6.71(\mathrm{~m}$, $1 \mathrm{H}), 7.05(\mathrm{dd}, J=8.8,2.4 \mathrm{~Hz}, 1 \mathrm{H}), 7.13-7.30(\mathrm{~m}, 7 \mathrm{H}), 7.73(\mathrm{~d}, J=$ $2.4 \mathrm{~Hz}, 1 \mathrm{H}), 7.94-7.96 \mathrm{ppm}(\mathrm{m}, 1 \mathrm{H}) ;{ }^{13} \mathrm{C}$ NMR $\left(75 \mathrm{MHz}, \mathrm{CD}_{3} \mathrm{OD}\right): \delta=$ $26.5,28.8,29.5,31.5,35.7,40.9,108.6,112.3,113.2,117.2,118.2$, $119.4,123.0,123.7,125.5$ (2C), 128.1 (2C), 128.2 (2C), 142.7, 147.3, 155.9, $156.7 \mathrm{ppm}$; ESI-MS $\mathrm{m} / \mathrm{z} 426[\mathrm{M}+\mathrm{Na}]^{+}$; Elemental analysis calcd (\%) for $\mathrm{C}_{24} \mathrm{H}_{25} \mathrm{~N}_{3} \mathrm{O}_{3}$ : C 71.44, H 6.25, N 10.41, found: C 71.37, H 6.51, N 10.58 .

Methyl 4-methoxy-2-(1H-pyrrol-1-yl)benzoate (20): To an icecooled solution of $19(1.0 \mathrm{~g}, 5.07 \mathrm{mmol})$ in $\mathrm{MeOH}(10.0 \mathrm{~mL}), \mathrm{SOCl}_{2}$ $(740 \mu \mathrm{L}, 10.15 \mathrm{mmol})$ was added dropwise and the reaction mixture was stirred at $25^{\circ} \mathrm{C}$ for $10 \mathrm{~h}$. Solvent was removed under reduced pressure and the residue was taken up with EtOAc and washed with a saturated solution of $\mathrm{NaHCO}_{3}$. The organic phase was dried over $\mathrm{Na}_{2} \mathrm{SO}_{4}$, filtered and evaporated to obtain methyl 4methoxy-2-nitrobenzoate (quantitative yield) which was carried on without any further purification. ${ }^{1} \mathrm{H}$ NMR $\left(300 \mathrm{MHz}, \mathrm{CDCl}_{3}\right): \delta=3.84$ $(\mathrm{s}, 3 \mathrm{H}), 3.99(\mathrm{~s}, 3 \mathrm{H}), 7.31(\mathrm{dd}, J=8.8,2.6 \mathrm{~Hz}, 1 \mathrm{H}), 7.42(\mathrm{~d}, J=2.6 \mathrm{~Hz}$, $1 \mathrm{H}), 7.88 \mathrm{ppm}(\mathrm{d}, J=8.8 \mathrm{~Hz}, 1 \mathrm{H})$; ESI-MS $\mathrm{m} / \mathrm{z} 212[\mathrm{M}+\mathrm{H}]^{+}$.

To a solution of methyl 4-methoxy-2-nitrobenzoate $(5.07 \mathrm{mmol})$ in EtOAc $(10.0 \mathrm{~mL}) \mathrm{SnCl}_{2} \cdot 2 \mathrm{H}_{2} \mathrm{O}(3.57 \mathrm{~g}, 15.84 \mathrm{mmol})$ was added and the reaction was stirred at $25^{\circ} \mathrm{C}$ for $2 \mathrm{~h}$. The reaction was quenched with a saturated solution of $\mathrm{NaHCO}_{3}$ and the aqueous phase was extracted with EtOAc $(3 \times 25.0 \mathrm{~mL})$. The combined organic layers were dried over $\mathrm{Na}_{2} \mathrm{SO}_{4}$, filtered and evaporated to afford methyl 2-amino-4-methoxybenzoate (quantitative yield) as a pale-yellow solid which was used in the next step without any further purification. ${ }^{1} \mathrm{H}$ NMR $\left(300 \mathrm{MHz}, \mathrm{CDCl}_{3}\right): \delta=3.78(\mathrm{~s}, 3 \mathrm{H}), 3.83(\mathrm{~s}$, $3 \mathrm{H}), 5.52(\mathrm{brs}, 2 \mathrm{H}), 6.11(\mathrm{~d}, J=2.4 \mathrm{~Hz}, 1 \mathrm{H}), 6.23(\mathrm{dd}, J=9.1,2.4 \mathrm{~Hz}$, $1 \mathrm{H}), 7.78 \mathrm{ppm}(\mathrm{d}, J=9.1,1 \mathrm{H})$; ESI-MS $\mathrm{m} / z 182[\mathrm{M}+\mathrm{H}]^{+}, 204[\mathrm{M}+$ $\mathrm{Na}]^{+}$.

Starting from methyl 2-amino-4-methoxybenzoate (300 mg, $1.70 \mathrm{mmol}$ ), the title compound was obtained following the same procedure reported for 17 . The crude was purified by means of chromatography on silica gel (petroleum ether/ $\mathrm{CHCl}_{3}$ 1:1) to afford pure compound 20 ( $87 \%$ yield) as a withe solid. ${ }^{1} \mathrm{H}$ NMR $(300 \mathrm{MHz}$, $\left.\mathrm{CDCl}_{3}\right): \delta=3.70(\mathrm{~s}, 3 \mathrm{H}), 3.83(\mathrm{~s}, 3 \mathrm{H}), 6.32(\mathrm{t}, J=2.2 \mathrm{~Hz}, 2 \mathrm{H}), 6.82(\mathrm{t}$, $J=2.2 \mathrm{~Hz}, 2 \mathrm{H}), 6.87-6.91(\mathrm{~m}, 2 \mathrm{H}), 7.84 \mathrm{ppm}(\mathrm{d}, J=8.3 \mathrm{~Hz}, 1 \mathrm{H})$; ESIMS $m / z 254[\mathrm{M}+\mathrm{Na}]^{+}$.

Methyl 2-(2-cyano-1 H-pyrrol-1-yl)-4-methoxybenzoate (21): To an ice-cooled solution of dry DMF $(1.0 \mathrm{~mL})$ and dry 1,2-DCE $(2.0 \mathrm{~mL})$, 
$(\mathrm{COCl})_{2}(135 \mu \mathrm{L}, 1.55 \mathrm{mmol})$ was added. The mixture was allowed to warm to $25^{\circ} \mathrm{C}$ and stirred for $15 \mathrm{~min}$. Then it was cooled to $0{ }^{\circ} \mathrm{C}$ and a solution of $20(325 \mathrm{mg}, 1.41 \mathrm{mmol})$ in dry 1,2-DCE $(1.0 \mathrm{~mL})$ was added. The reaction was stirred at $25^{\circ} \mathrm{C}$ for further $15 \mathrm{~min}$. A solution of $\mathrm{NH}_{2} \mathrm{OH} \cdot \mathrm{HCl}(108 \mathrm{mg}, 1.55 \mathrm{mmol})$ and pyridine $(125 \mu \mathrm{L}$, $1.55 \mathrm{mmol})$ in dry DMF $(1.0 \mathrm{~mL})$ was added and the mixture was stirred at $120^{\circ} \mathrm{C}$ for $10 \mathrm{~h}$. A saturated solution of $\mathrm{NaHCO}_{3}$ was added dropwise and the aqueous phase was extracted with EtOAc $(3 \times 10.0 \mathrm{~mL})$. The combined organic layers were dried over anhydrous $\mathrm{Na}_{2} \mathrm{SO}_{4}$, filtered, and evaporated. The crude was purified by means of chromatography on silica gel (petroleum ether/ $\mathrm{Et}_{2} \mathrm{O}$ 1:1) to afford title compound ( $47 \%$ yield) as a colorless solid. ${ }^{2} \mathrm{H}$ NMR $\left(300 \mathrm{MHz}, \mathrm{CDCl}_{3}\right): \delta=3.72(\mathrm{~s}, 3 \mathrm{H}), 3.90(\mathrm{~s}, 3 \mathrm{H}), 6.33-6.35(\mathrm{~m}, 1 \mathrm{H})$, $6.89(\mathrm{~d}, J=2.6 \mathrm{~Hz}, 1 \mathrm{H}), 6.92-6.94(\mathrm{~m}, 1 \mathrm{H}), 6.97(\mathrm{dd}, J=4.0,1.6 \mathrm{~Hz}$ $1 \mathrm{H}), 7.03(\mathrm{dd}, J=8.8,2.3 \mathrm{~Hz}, 1 \mathrm{H}), 8.06 \mathrm{ppm}(\mathrm{d}, J=8.8 \mathrm{~Hz}, 1 \mathrm{H})$; ESIMS $m / z 279[\mathrm{M}+\mathrm{Na}]^{+}$.

\section{9-Methoxy-4H-benzo[f]pyrrolo[1,2-a][1,4]diazepin-6(5H)-one}

(22): To a stirred suspension of $21(290 \mathrm{mg}, 1.13 \mathrm{mmol})$ and $\mathrm{CoCl}_{2}$ (294 mg, $2.26 \mathrm{mmol})$ in $\mathrm{MeOH}(10.0 \mathrm{~mL}), \mathrm{NaBH}_{4}(420 \mathrm{mg}$, $11.30 \mathrm{mmol}$ ) was added and reaction was stirred at $25^{\circ} \mathrm{C}$ for $20 \mathrm{~min}$. $\mathrm{HCl}(2 \mathrm{~N})$ was added and solvent was removed under reduced pressure. The solution was basified with $2 \mathrm{~N} \mathrm{NaOH}$ and the aqueous phase was extracted with EtOAc $(3 \times 10.0 \mathrm{~mL})$. The combined organic layers were dried over $\mathrm{Na}_{2} \mathrm{SO}_{4}$, filtered, and evaporated. The crude was purified by means of chromatography on silica gel (EtOAc) to afford title compound (64\% yield) as a colorless solid. ' $\mathrm{H}$ NMR $\left(300 \mathrm{MHz}, \mathrm{CDCl}_{3}\right): \delta=3.90(\mathrm{~s}, 3 \mathrm{H}), 4.20(\mathrm{brd}, 2 \mathrm{H})$, $6.12(\mathrm{~s}, 1 \mathrm{H}), 6.28(\mathrm{~s}, 1 \mathrm{H}), 6.87-6.92(\mathrm{~m}, 2 \mathrm{H}), 7.03(\mathrm{~s}, 1 \mathrm{H}), 7.32$ (brs, $1 \mathrm{H}), 7.97 \mathrm{ppm}(\mathrm{d}, J=8.8 \mathrm{~Hz}, 1 \mathrm{H})$; ESI-MS $\mathrm{m} / \mathrm{z} 229[\mathrm{M}+\mathrm{H}]^{+}, 251$ $[\mathrm{M}+\mathrm{Na}]^{+}$.

6-Oxo-5,6-dihydro-4H-benzo[f]pyrrolo[1,2-a][1,4]diazepin-9-yl-6phenylhexylcarbamate $(5 \mathrm{~h})$ : Starting from 22 , hydroxy- $4 \mathrm{H}$-benzo[f]pyrrolo[1,2-a][1,4]diazepin-6(5H)-one was obtained following the same procedure reported for $\mathbf{1 4}$. The crude was purified by means of chromatography on silica gel $\left(\mathrm{CHCl}_{3} / \mathrm{EtOAC} 1: 1\right)$ to afford compound hydroxy-4H-benzo[f]pyrrolo[1,2-a][1,4]diazepin-6(5H)-one ( $50 \%$ yield) as a colorless solid. ${ }^{1} \mathrm{H}$ NMR $\left(300 \mathrm{MHz}\right.$, [ $\mathrm{D}_{6}$ ]acetone): $\delta=$ $4.22(\mathrm{~s}, 2 \mathrm{H}), 6.11(\mathrm{~d}, J=2.3 \mathrm{~Hz}, 1 \mathrm{H}), 6.20-6.24(\mathrm{~m}, 1 \mathrm{H}), 6.85-6.93$ $(\mathrm{m}, 2 \mathrm{H}), 7.10-7.12(\mathrm{~m}, 1 \mathrm{H}), 7.81-7.86(\mathrm{~m}, 2 \mathrm{H}), 9.42 \mathrm{ppm}(\mathrm{brs}, 1 \mathrm{H})$; ESI-MS $m / z 213[M-H]^{-}$.

Starting from hydroxy-4H-benzo[f]pyrrolo[1,2-a][1,4]diazepin-6(5H)one $(14 \mathrm{mg}, 0.06 \mathrm{mmol})$ and 6-phenylhexyl isocyanate $7 \mathrm{~b}(50 \mathrm{mg}$, $0.25 \mathrm{mmol}$ ), the title compound was obtained following the same procedure reported for $5 \mathrm{a}$. The crude was purified by means of chromatography on silica gel $\left(\mathrm{MeOH} / \mathrm{CH}_{2} \mathrm{Cl}_{2} \quad 1: 20\right)$ to afford title compound $\mathbf{5}$ h $\left(60 \%\right.$ yield) as a colorless solid. ${ }^{1} \mathrm{H}$ NMR $(300 \mathrm{MHz}$, $\left.\mathrm{CDCl}_{3}\right): \delta=1.38-1.41(\mathrm{~m}, 4 \mathrm{H}), 1.57-1.70(\mathrm{~m}, 4 \mathrm{H}), 2.62(\mathrm{t}, J=7.6 \mathrm{~Hz}$, $2 \mathrm{H}), 3.27(\mathrm{q}, J=6.1 \mathrm{~Hz}, 2 \mathrm{H}), 4.21(\mathrm{~s}, 2 \mathrm{H}), 5.14(\mathrm{brs}, 1 \mathrm{H}), 6.11$ (brd, $1 \mathrm{H}), 6.27(\mathrm{t}, J=2.9 \mathrm{~Hz}, 1 \mathrm{H}), 7.01(\mathrm{brd}, 1 \mathrm{H}), 7.12-7.31(\mathrm{~m}, 7 \mathrm{H})$, $7.96 \mathrm{ppm}(\mathrm{d}, J=8.5 \mathrm{~Hz}, 1 \mathrm{H}) ;{ }^{13} \mathrm{C}$ NMR $\left(75 \mathrm{MHz}, \mathrm{CDCl}_{3}\right): \delta=26.8$, $29.1,29.9,31.6,36.1,37.7,41.6,107.3,110.8,115.7,119.3,120.9$, $125.9,128.5$ (2C), 128.6 (2C), 132.2, 133.6, 138.6, 142.8, 153.7, 154.6, $169.6 \mathrm{ppm}$; ESI-MS m/z $418[\mathrm{M}+\mathrm{H}]^{+}$; Elemental analysis calcd (\%) for $\mathrm{C}_{25} \mathrm{H}_{27} \mathrm{~N}_{3} \mathrm{O}_{3}$ : C 71,92, H 6,52, N 10,06, found: C 72.18, H 6.27, N 10.34 .

Methyl 1-(2-cyano-5-methoxyphenyl)-1H-pyrrole-2-carboxylate (24): To a stirred solution of methyl $1 \mathrm{H}$-pyrrole-2-carboxylate $(1.0 \mathrm{~g}$, $8.00 \mathrm{mmol})$ in dry DMF $(25.0 \mathrm{~mL}), \mathrm{Cs}_{2} \mathrm{CO}_{3}(13.0 \mathrm{~g}, 40.00 \mathrm{mmol})$ and $23(1.5 \mathrm{~g}, 9.60 \mathrm{mmol})$ were added and the reaction was stirred at $50^{\circ} \mathrm{C}$ under $\mathrm{N}_{2}$ atmosphere for $12 \mathrm{~h}$. Solvent was removed under reduced pressure and the crude was taken up with a saturated so- lution of $\mathrm{NH}_{4} \mathrm{Cl}$. The aqueous phase was extracted with $\mathrm{CH}_{2} \mathrm{Cl}_{2}(3 \times$ $25.0 \mathrm{~mL}$ ) and the combined organic layers were dried over $\mathrm{Na}_{2} \mathrm{SO}_{4}$, filtered, and evaporated. The crude was purified by means of chromatography on silica gel (EtOAc/petroleum ether 1:6) to afford compound title compound ( $30 \%$ yield) as a colorless solid. ${ }^{1} \mathrm{H}$ NMR $\left(300 \mathrm{MHz}, \mathrm{CDCl}_{3}\right): \delta=3.74(\mathrm{~s}, 3 \mathrm{H}), 3.87(\mathrm{~s}, 3 \mathrm{H}), 6.37(\mathrm{dd}, J=3.8$, $2.9 \mathrm{~Hz}, 1 \mathrm{H}), 6.90(\mathrm{~d}, J=2.5 \mathrm{~Hz}, 1 \mathrm{H}), 6.94(\mathrm{q}, J=2.6 \mathrm{~Hz}, 1 \mathrm{H}), 7.00$ (dd, J=8.7, $2.5 \mathrm{~Hz}, 1 \mathrm{H}), 7.13$ (dd, J=3.9, $1.7 \mathrm{~Hz}, 1 \mathrm{H}), 7.64 \mathrm{ppm}(\mathrm{d}$, $J=8.7 \mathrm{~Hz}, 1 \mathrm{H})$; ESI-MS m/z $257[\mathrm{M}+\mathrm{H}]^{+}, 279[\mathrm{M}+\mathrm{Na}]^{+}$.

9-Hydroxy-5,6-dihydro-4H-benzo[f]pyrrolo[1,2-a][1,4]diazepin-4one (25): Starting from $24(600 \mathrm{mg}, 2.34 \mathrm{mmol})$, 9-methoxy-5,6-dihydro-4H-benzo[f]pyrrolo[1,2-a][1,4]diazepin-4-one was obtained following the same procedure reported for $\mathbf{2 2}$. The crude was purified by means of chromatography on silica gel (EtOAc/petroleum ether 1:1) to afford compound 9-methoxy-5,6-dihydro-4H-benzo[f]pyrrolo[1,2-a][1,4]diazepin-4-one (71\% yield) as a colorless solid. ${ }^{1} \mathrm{H}$ NMR $\left(300 \mathrm{MHz}, \mathrm{CDCl}_{3}\right): \delta=3.80(\mathrm{~s}, 3 \mathrm{H}), 4.14(\mathrm{~s}, 2 \mathrm{H}), 6.36-6.47$ $(\mathrm{m}, 1 \mathrm{H}), 6.75(\mathrm{dd}, J=8.3,1.9 \mathrm{~Hz}, 1 \mathrm{H}), 6.83(\mathrm{~d}, J=2.3 \mathrm{~Hz}, 1 \mathrm{H}), 7.07-$ $7.15(\mathrm{~m}, 1 \mathrm{H}), 7.15-7.24(\mathrm{~m}, 2 \mathrm{H}), 8.23 \mathrm{ppm}$ (brs, 1H); ESI-MS m/z $229[\mathrm{M}+\mathrm{H}]^{+}, 251[\mathrm{M}+\mathrm{Na}]^{+}$.

Starting from 9-methoxy-5,6-dihydro-4H-benzo[f]pyrrolo[1,2-a][1,4]diazepin-4-one ( $380 \mathrm{mg}, 1.66 \mathrm{mmol}$ ), the title compound was obtained following the same procedure reported for $\mathbf{1 4}$. The crude was purified by means of chromatography on silica gel (EtOAc) to afford title compound ( $50 \%$ yield) as a colorless solid. ${ }^{1} \mathrm{H}$ NMR (300 MHz, CD $\mathrm{OD}): \delta=4.08(\mathrm{~s}, 2 \mathrm{H}), 6.42(\mathrm{t}, J=3.1 \mathrm{~Hz}, 1 \mathrm{H}), 6.74$ (dd, $J=8.2,2.1 \mathrm{~Hz}, 1 \mathrm{H}), 6.85(\mathrm{~d}, J=2.2 \mathrm{~Hz}, 1 \mathrm{H}), 7.02(\mathrm{dd}, J=3.8,1.1 \mathrm{~Hz}$, $1 \mathrm{H}), 7.21(\mathrm{~d}, J=8.2 \mathrm{~Hz}, 1 \mathrm{H}), 7.32-7.40 \mathrm{ppm}(\mathrm{m}, 1 \mathrm{H})$; ESI-MS $\mathrm{m} / \mathrm{z}$ $215[\mathrm{M}+\mathrm{H}]^{+}, 237[\mathrm{M}+\mathrm{Na}]^{+}$.

\section{4-Oxo-5,6-dihydro-4H-benzo[f]pyrrolo[1,2-a][1,4]diazepin-9-yl-(6-} phenylhexyl)carbamate (5i): Starting from $25(10 \mathrm{mg}, 0.05 \mathrm{mmol})$ and 6-phenylhexyl isocyanate $7 \mathbf{b}(13 \mathrm{mg}, 0.06 \mathrm{mmol})$, the title compound was obtained following the same procedure reported for $5 \mathrm{a}$. The crude was purified by means of chromatography on silica gel $\left(\mathrm{MeOH} / \mathrm{CH}_{2} \mathrm{Cl}_{2} 1: 20\right)$ to afford the title compound $(52 \%$ yield) as a colorless solid. ${ }^{1} \mathrm{H}$ NMR $\left(300 \mathrm{MHz}, \mathrm{CDCl}_{3}\right): \delta=1.33-1.44$ $(\mathrm{m}, 4 \mathrm{H}), 1.48-1.71(\mathrm{~m}, 4 \mathrm{H}), 2.61(\mathrm{t}, J=5.1 \mathrm{~Hz}, 2 \mathrm{H}), 3.24(\mathrm{q}, J=$ $6.6 \mathrm{~Hz}, 2 \mathrm{H}), 4.17(\mathrm{brd}, 2 \mathrm{H}), 5.25(\mathrm{t}, J=4.2 \mathrm{~Hz}, 1 \mathrm{H}), 6.42(\mathrm{t}, J=$ $3.3 \mathrm{~Hz}, 1 \mathrm{H}), 7.01(\mathrm{dd}, J=8.2,2.1 \mathrm{~Hz}, 1 \mathrm{H}), 7.07-7.22(\mathrm{~m}, 6 \mathrm{H}), 7.22-$ $7.33(\mathrm{~m}, 3 \mathrm{H}), 7.45 \mathrm{ppm}(\mathrm{t}, J=5.2 \mathrm{~Hz}, 1 \mathrm{H})$; ESI-MS m/z $375[\mathrm{M}+\mathrm{H}]^{+}$; HRMS (ESI) $\mathrm{m} / \mathrm{z}$ calcd for $\mathrm{C}_{25} \mathrm{H}_{28} \mathrm{~N}_{3} \mathrm{O}_{3}{ }^{+}: 418.2125$, found 418.2117 $[\mathrm{M}+\mathrm{H}]^{+}$; calcd for: $\mathrm{C}_{25} \mathrm{H}_{27} \mathrm{~N}_{3} \mathrm{NaO}_{3}^{+}: 440.1945$, found 440.1936 [M+ $\mathrm{Na}^{+}$, calcd for $\mathrm{C}_{50} \mathrm{H}_{55} \mathrm{~N}_{6} \mathrm{O}_{6}{ }^{+}$: 835.4178, found 835.4168 $[2 \mathrm{M}+\mathrm{H}]^{+}$; Elemental analysis calcd (\%) for $\mathrm{C}_{25} \mathrm{H}_{27} \mathrm{~N}_{3} \mathrm{O}_{3}$ : C 71.92, $\mathrm{H}$ 6.52, N 10.06, found C 72.11, H 6.35, N 10.20.

4-Oxo-5,6-dihydro-4H-benzo[f]pyrrolo[1,2-a][1,4]diazepin-9-yl-(2(2-phenoxyethoxy)ethyl) carbamate $(5 \mathrm{j})$ : Starting from 25 (10 mg, $0.05 \mathrm{mmol}$ ) and isocyanate $26 \mathrm{a}(13 \mathrm{mg}, 0.06 \mathrm{mmol})$, the title compound was obtained following the same procedure reported for $5 \mathrm{a}$. The crude was purified by means of chromatography on silica gel $\left(\mathrm{MeOH} / \mathrm{CH}_{2} \mathrm{Cl}_{2} 1: 20\right)$ to afford title compound (55\% yield) as a colorless solid. ' ${ }^{1} \mathrm{H} \mathrm{NMR}\left(300 \mathrm{MHz}, \mathrm{CDCl}_{3}\right)$ : $\delta=3.46-3.54(\mathrm{~m}, 2 \mathrm{H})$, $3.71(\mathrm{t}, J=4.8 \mathrm{~Hz}, 2 \mathrm{H}), 3.80-3.92(\mathrm{~m}, 2 \mathrm{H}), 4.07-4.25(\mathrm{~m}, 4 \mathrm{H}), 5.66(\mathrm{t}$, $J=4.5 \mathrm{~Hz}, 1 \mathrm{H}), 6.43(\mathrm{t}, J=3.3 \mathrm{~Hz}, 1 \mathrm{H}), 6.89-6.99(\mathrm{~m}, 3 \mathrm{H}), 7.00-7.17$ $(\mathrm{m}, 4 \mathrm{H}), 7.20(\mathrm{~s}, 1 \mathrm{H}), 7.23-7.34 \mathrm{ppm}(\mathrm{m}, 3 \mathrm{H}) ;{ }^{13} \mathrm{C}$ NMR $(75 \mathrm{MHz}$, $\left(\mathrm{CDCl}_{3}\right): \delta=41.3,43.2,67.5,69.9,70.1,111.2,114.8,116.8,118.7$, 119.9, 121.4, 125.1, 128.7, 129.0, 129.3, 129.8, 140.0, 151.7, 154.4, 158.8 ppm; ESI-MS m/z $422[\mathrm{M}+\mathrm{H}]^{+}$(100); Elemental analysis calcd (\%) for $\mathrm{C}_{23} \mathrm{H}_{23} \mathrm{~N}_{3} \mathrm{O}_{5}$ : C 65.55, H 5.50, N 9.97, found: $\mathrm{C} 65.23, \mathrm{H}$ 5.29, N 9.76 . 
4-0xo-5,6-dihydro-4H-benzo[f]pyrrolo[1,2-a][1,4]diazepin-9-yl-(2(2-(2-fluorophenoxy)ethoxy)ethyl) carbamate $(5 \mathbf{k})$ : Starting from $25(10 \mathrm{mg}, 0.05 \mathrm{mmol})$ and isocyanate $26 \mathrm{~b}(14 \mathrm{mg}, 0.06 \mathrm{mmol})$, the title compound was obtained following the same procedure reported for $5 \mathrm{a}$. The crude was purified by means of chromatography on silica gel $\left(\mathrm{MeOH} / \mathrm{CH}_{2} \mathrm{Cl}_{2} 1: 20\right)$ to afford title compound (47\% yield) as a colorless solid. ${ }^{1} \mathrm{H}$ NMR $\left(300 \mathrm{MHz}, \mathrm{CDCl}_{3}\right): \delta=3.49$ (q, $J=10.3 \mathrm{~Hz}, 2 \mathrm{H}), 3.71(\mathrm{t}, J=5.0 \mathrm{~Hz}, 2 \mathrm{H}), 3.84-3.93(\mathrm{~m}, 2 \mathrm{H}), 4.14-$ $4.26(\mathrm{~m}, 4 \mathrm{H}), 5.65(\mathrm{t}, J=5.6 \mathrm{~Hz}, 1 \mathrm{H}), 6.42(\mathrm{dd}, J=3.8,2.9 \mathrm{~Hz}, 1 \mathrm{H})$, 6.86-6.96 (m, 1 H), 6.96-7.11 (m, 4H), 7.11-7.17 (m, 3H), 7.17-7.23 $(\mathrm{m}, 1 \mathrm{H}), 7.28 \mathrm{ppm}(\mathrm{s}, 1 \mathrm{H}) ;{ }^{13} \mathrm{C}$ NMR $\left(75 \mathrm{MHz}, \mathrm{CDCl}_{3}\right): \delta=41.3,43.2$, $69.3,69.7,70.2,111.3,115.8,116.60\left(d, J_{C-F}=18.2 \mathrm{~Hz}\right), 116.9,118.9$, 120.0, $121.98\left(d, J_{C-F}=6.8 \mathrm{~Hz}\right), 124.57\left(d, J_{C-F}=3.9 \mathrm{~Hz}\right), 125.3,128.8$, $129.3,140.0,146.93\left(d, J_{C-F}=10.6 \mathrm{~Hz}\right), 151.7,153.13\left(d, J_{C-F}=\right.$ $245.6 \mathrm{~Hz}), 154.4,164.2 \mathrm{ppm}$; ESI-MS $\mathrm{m} / \mathrm{z} 440[\mathrm{M}+\mathrm{H}]^{+}$; Elemental analysis calcd (\%) for $\mathrm{C}_{23} \mathrm{H}_{22} \mathrm{FN}_{3} \mathrm{O}_{5}$ : C 62.86, $\mathrm{H} 5.05, \mathrm{~N} 9.56$, found: $\mathrm{C}$ 63.12, H 5.18, N 9.47.

4-Oxo-5,6-dihydro-4H-benzo[f]pyrrolo[1,2-a][1,4]diazepin-9-yl-(2(2-(4-fluorophenoxy)ethoxy)ethyl) carbamate (5I): Starting from $25(10 \mathrm{mg}, 0.05 \mathrm{mmol})$ and isocyanate $26 \mathrm{c}(14 \mathrm{mg}, 0.06 \mathrm{mmol})$, the title compound was obtained following the same procedure reported for $5 \mathrm{a}$. The crude was purified by means of chromatography on silica gel ( $\left.\mathrm{MeOH} / \mathrm{CH}_{2} \mathrm{Cl}_{2} 1: 20\right)$ to afford title compound ( $43 \%$ yield) as a colorless solid. ${ }^{1} \mathrm{H}$ NMR $\left(300 \mathrm{MHz}, \mathrm{CDCl}_{3}\right): \delta=3.50$ $(q, J=5.2 \mathrm{~Hz}, 2 \mathrm{H}), 3.70(\mathrm{t}, J=5.0 \mathrm{~Hz}, 2 \mathrm{H}), 3.82-3.89(\mathrm{~m}, 2 \mathrm{H}), 4.07-$ $4.14(\mathrm{~m}, 2 \mathrm{H}), 4.20(\mathrm{brd}, J=3.4 \mathrm{~Hz}, 2 \mathrm{H}), 5.61(\mathrm{t}, J=5.7 \mathrm{~Hz}, 1 \mathrm{H}), 6.43$ $(\mathrm{t}, J=3.8 \mathrm{~Hz}, 1 \mathrm{H}), 6.81-6.92(\mathrm{~m}, 2 \mathrm{H}), 6.92-7.11(\mathrm{~m}, 4 \mathrm{H}), 7.11-7.17$ $(\mathrm{m}, 2 \mathrm{H}), 7.17-7.22(\mathrm{~m}, 1 \mathrm{H}), 7.26-7.31 \mathrm{ppm}(\mathrm{m}, 1 \mathrm{H}) ;{ }^{13} \mathrm{C} \mathrm{NMR}$ $\left(75 \mathrm{MHz}, \mathrm{CDCl}_{3}\right): \delta=41.3,43.1,68.2,69.9,70.1,111.3,115.9\left(\mathrm{~d}, J_{\mathrm{C}-\mathrm{F}}=\right.$ $8.0 \mathrm{~Hz}), 116.1\left(\mathrm{~d}, J_{\mathrm{C}-\mathrm{F}}=23.1 \mathrm{~Hz}\right), 116.8,118.8,119.9,125.2,128.6$, $128.9,129.2,140.0,151.6,154.3,155.0\left(d, J_{C-F}=2.1 \mathrm{~Hz}\right), 157.6\left(d, J_{c}\right.$ $\mathrm{F}=238.7 \mathrm{~Hz}), 164.2 \mathrm{ppm}$; ESI-MS m/z $440[\mathrm{M}+\mathrm{H}]^{+}$; Elemental analysis calcd (\%) for $\mathrm{C}_{23} \mathrm{H}_{22} \mathrm{FN}_{3} \mathrm{O}_{5}$ : C 62.86, H 5.05, N 9.56, found: $\mathrm{C}$ $62.67, \mathrm{H} 4.78, \mathrm{~N} 9.21$.

\section{Molecular docking studies}

a) Ligand preparation: Three-dimensional structures of all compounds in this study were built by means of Maestro (Maestro, version 9.3, Schrödinger LLC, New York, NY, 2012). Molecular energy minimizations were performed by means of MacroModel (MacroModel version 9.9, Schrödinger LLC, New York, NY, 2012) using the Optimized Potentials for Liquid Simulations-all atom (OPLS-AA) force field $2005 .{ }^{[41]}$ The solvent effects were simulated using the analytical Generalized-Born/Surface Area (GB/SA) model, ${ }^{[42]}$ and no cutoff for nonbonded interactions was selected. Polak-Ribiere conjugate gradient (PRCG) method with 1000 maximum iterations and 0.001 gradient convergence threshold was employed. All compounds reported in this paper were treated by LigPrep application (LigPrep version 2.5, Schrödinger LLC, New York, NY, 2012), implemented in Maestro suite 2011, generating the most probable ionization state of any possible enantiomers and tautomers at cellular $\mathrm{pH}$ value $(7 \pm 0.5)$ and also for avoiding potential error in the structures.

b) Protein preparation: The three-dimensional structure of FAAH (PDB ID: $3 \mathrm{PPM}^{[43]}$ ) was taken from the PDB and imported into Schrödinger Maestro molecular modeling environment. Water molecules and compounds used for the crystallization were removed from the available experimental structure. The obtained enzyme was submitted to protein preparation wizard implemented in Maestro suite 2012. This protocol through a series of computational steps, allowed us to obtain a reasonable starting structure of the protein for molecular docking calculations by a series of computational steps. In particular, we performed three steps to: 1) add hydrogen atoms, 2) optimize the orientation of hydroxy groups, Asn, and $\mathrm{Gln}$, and the protonation state of His, and 3) perform a constrained refinement with the impref utility, setting the max RMSD of 0.30 . The impref utility consists of a cycles of energy minimization based on the impact molecular mechanics engine and on the OPLS_2005 force field..$^{[41]}$

c) Molecular docking: Molecular docking was carried out using the Schrödinger suite 2012 by applying the IFD protocol (Schrödinger Suite 2012 Induced Fit Docking protocol; Glide version 5.8, Schrödinger LLC, New York, NY, 2012; Prime version 3.1, Schrödinger LLC, New York, NY, 2012). This procedure induces conformational changes in the binding site to accommodate the ligand and exhaustively identify possible binding modes and associated conformational changes by side-chain sampling and backbone minimization. The protein and the ligands used were prepared as reported in the previous paragraphs. The boxes for docking calculation were built taking into account the centroid of the co-crystallized ligand for FAAH enzyme. Complexes within $30.0 \mathrm{kcal} \mathrm{mol}^{-1}$ of minimum energy structure were taken forward for redocking. The Glide redocking stage was performed by XP (Extra Precision) methods. The calculations were performed using default IFD protocol parameters. No hydrogen bonding or other constraints were used. The choice of IFD coupled to XP was done after the assessment of two docking protocols (IFD-SP and IFD-XP). From the computational outputs we observed that IFD-XP was able to correctly accommodate the co-crystallized ligands, belonging to the FAAH crystal structures 3PPM, 3QJ9 and 2VYA, with lower RMSD than IFD-SP (data not shown).

\section{Enzymatic assays}

FAAH and MAGL activities were detected in cells as previously described. ${ }^{[4-45]}$ In particular, AEA hydrolysis was measured by incubating samples with the $10000 \times g$ membrane fraction of rat brain (70 $\mu \mathrm{g}$ per sample) and synthetic $\mathrm{N}$-arachidonoyl- $\left[{ }^{14} \mathrm{C}\right]$ ethanolamine $\left(110 \mathrm{mCimmol}^{-1}, \mathrm{ARC}\right.$, St. Louis, MO, USA) properly diluted with AEA (Tocris Bioscience, Avonmouth, Bristol, UK) in Tris. $\mathrm{HCl} 50 \mathrm{~mm}$, at $\mathrm{pH} 9.00-10.00$ at $37^{\circ} \mathrm{C}$ for $30 \mathrm{~min}$. After incubation, the amount of $\left[{ }^{14} \mathrm{C}\right]$ ethanolamine produced was measured by scintillation counting of the aqueous phase after extraction of the incubation mixture with two volumes of $\mathrm{CHCl}_{3} / \mathrm{MeOH} \mathrm{1:1} \mathrm{(v/v).} \mathrm{2-AG} \mathrm{hydrolysis}$ was measured by incubating the $10000 \times g$ cytosolic fraction of COS-7 cells (100 $\mu \mathrm{g}$ per sample), which contains high levels of MAGL, and synthetic 2-arachidonoyl-[ $\left.{ }^{3} \mathrm{H}\right]$ glycerol $\left(40 \mathrm{Cimmol}^{-1}\right.$, ARC, St. Louis, MO, USA) properly diluted with 2-AG (Cayman Chemicals, Ann Arbor, MI, USA) in Tris. $\mathrm{HCl} 50 \mathrm{~mm}$, at $\mathrm{pH} 7.0$ at $37^{\circ} \mathrm{C}$ for $20 \mathrm{~min}$. After incubation, the amount of $\left[{ }^{3} \mathrm{H}\right]$ glycerol produced was measured by scintillation counting of the aqueous phase after extraction of the incubation mixture with two volumes of $\mathrm{CHCl}_{3} / \mathrm{MeOH}$ 1:1 $(\mathrm{v} / \mathrm{v})$. All data are expressed as means \pm SD of three separate experiments of the concentration exerting $50 \%$ inhibition of $\left[{ }^{14} \mathrm{C}\right] \mathrm{AEA}$ hydrolysis $\left(\mathrm{IC}_{50}\right)$ calculated by fitting sigmoidal concentration-response curves by GraphPad Prism software.

\section{Competition binding assay}

Membranes from HEK-293 cells overexpressing the respective human recombinant $\mathrm{CB}_{1}$ receptor $\left(B_{\max }=2.5 \mathrm{pmolmg} \mathrm{mg}^{-1}\right.$ protein) and human recombinant $\mathrm{CB}_{2}$ receptor $\left(B_{\max }=4.7 \mathrm{pmol} \mathrm{mg}^{-1}\right.$ protein) were incubated with $\left[{ }^{3} \mathrm{H}\right] \mathrm{CP}-55,940\left(0.14 \mathrm{~nm}, K_{\mathrm{d}}=0.18 \mathrm{~nm}\right.$; 
and $0.084 \mathrm{~nm}, K_{d}=0.31 \mathrm{~nm}$, respectively, for $\mathrm{CB}_{1}$ and $\mathrm{CB}_{2}$ receptors) as the high-affinity ligand. Competition curves were performed as previously reported ${ }^{[46]}$ by displacing $\left[{ }^{3} \mathrm{H}\right] \mathrm{CP}-55,940$ with increasing concentration of compounds $(0.1-50 \mu \mathrm{M})$. Nonspecific binding was defined by $10 \mu \mathrm{M}$ of WIN55,212-2 as the heterologous competitor ( $K_{\mathrm{i}}$ values 9.2 and $2.1 \mathrm{~nm}$, respectively, for $\mathrm{CB}_{1}$ and $\mathrm{CB}_{2}$ receptors). $\mathrm{IC}_{50}$ values were determined for compounds showing $>50 \%$ displacement at $10 \mu \mathrm{M}$. All compounds were tested following the procedure described by the manufacturer (PerkinElmer, Italy). Displacement curves were generated by incubating drugs with $\left[{ }^{3} \mathrm{H}\right] \mathrm{CP}$ 55,940 for $90 \mathrm{~min}$ at $30^{\circ} \mathrm{C} . K_{\mathrm{i}}$ values were calculated by applying the Cheng-Prusoff equation to the $I_{50}$ values (obtained by GraphPad Prism) for the displacement of the bound radioligand by increasing concentrations of the test compound. Data represent mean values of three separate experiments performed in duplicate and are expressed as the average of $K_{\mathrm{i}} \pm \mathrm{SD}$.

\section{Cellular in vitro study}

a) Cell culture and treatments: IMR32 cells line (obtained from American Type Culture Collection, ATCC), were cultured in EMEM supplemented with $10 \%$ fetal bovine serum (Lonza, Milan, Italy), $1 \%$ of L-glutammine (Lonza, Milan, Italy) and $1 \%$ of penicillin/ streptomycin antibiotics (Lonza, Milan, Italy) at $37^{\circ} \mathrm{C}$ in $5 \% \mathrm{CO}_{2}$. The different formulations (compounds $3,5 \mathbf{h}$, and $5 \mathbf{i}$ ) were dissolved in DMSO as stock solutions at a final concentration of $10 \mathrm{~mm}$. Stock solutions were then diluted with cell culture medium, EMEM with Earle's Balanced Salt Solution, to obtain an intermediate dose solution $(100 \mu \mathrm{M})$, to be used for the used dilutions $(50,10,5,1,0.5$, and $0.1 \mu \mathrm{M})$. Control vehicle was represented by DMSO ranging from $0.5 \%$ to $0.001 \%$.

b) Cytotoxicity determination: IMR32 cells were seeded 100000 cells per well in 96-well plate and were grown to confluence, then were treated with the tested substances in EMEM supplemented with $10 \%$ FBS. The effects of tested compounds on cellular morphology were checked after $24 \mathrm{~h}$ using a built-in camera in an inverted Nikon Eclipse microscope (20x magnification). Cytotoxicity was determined by LDH release in the media, measured by enzymatic assay: in the first step $\mathrm{NAD}^{+}$is reduced to $\mathrm{NADH} / \mathrm{H}^{+}$by $\mathrm{LDH}$-catalyzed conversion of lactate into pyruvate; in the second step the catalyst (diaphorase) transfers $\mathrm{H} / \mathrm{H}^{+}$from $\mathrm{NADH} / \mathrm{H}^{+}$to tetrazolium salt which is reduced to formazan. For total release of intracellular LDH (positive control of $100 \%$ cell death), a triplicate set of IMR32 cells were treated with $1 \%$ Triton X-100 for 30 min at $37^{\circ} \mathrm{C}$, according to the manufacturer's protocol (Roche, Mannheim, Germany). The amount of LDH in the supernatant was determined and calculated according to kit instructions. The amount of LDH release in each sample was determined by measuring the absorbance at $490 \mathrm{~nm}$ using a microplate spectrophotometer. All tests were performed at least in triplicate. The absorbance measured from three wells was averaged, and the percentage of LDH released was calculated as arbitrary units of change relative to $1 \%$ Triton X-100 treated cells.

c) Extraction of nuclear proteins: For nuclear extracts, IMR32 cells were seeded in a $100 \mathrm{~mm}$ petri dish $\left(3 \times 10^{6}\right.$ cells). After treatments with various compounds, cells were detached, washed with icecold $1 \times$ PBS, and cell pellets were resuspended in hypotonic buffer containing $10 \mathrm{~mm}$ HEPES ( $\mathrm{pH}$ 7.9), $10 \mathrm{~mm} \mathrm{KCl}, 1.5 \mathrm{~mm} \mathrm{MgCl}{ }_{2}, 0.3 \%$ Nonidet P-40, $0.5 \mathrm{~mm}$ dithithreitiol, $0.5 \mathrm{~mm}$ phenylmethylsulfonyl fluoride and protease and phosphatase inhibitor cocktails. The lysates were incubated for $15 \mathrm{~min}$ on ice with intermitted mixing and then centrifuged at $24500 \times g$ for $15 \mathrm{~min}$ at $4^{\circ} \mathrm{C}$. The superna- tant containing the cytosolic proteins was removed and pellet containing the nuclei were resuspended in extraction buffer containing $20 \mathrm{~mm}$ HEPES (pH 7.9), $0.6 \mathrm{~m} \mathrm{KCl}, 1.5 \mathrm{~mm} \mathrm{MgCl} 2,20 \%$ glycerol, $0.5 \mathrm{~mm}$ phenylmethylsulfonyl fluoride and protease and phosphatase inhibitor cocktails and then incubated for 30 min on ice with intermitted mixing. Samples were centrifuged at $21100 \times g$ for $15 \mathrm{~min}$ to obtain supernatants containing nuclear fractions. Protein concentration was determined by Bradford analysis (Bio-Rad protein assay; Bio-Rad, Milan, Italy).

d) Western blot analysis: After protein quantification, $60 \mu \mathrm{g}$ boiled proteins were separated by $10 \%$ SDS-PAGE. Gels were electro-blotted onto nitrocellulose membranes and then blocked for $90 \mathrm{~min}$ in Tris-buffered saline, pH 7.5, containing $0.5 \%$ Tween 20 and $5 \%(w / v)$ skim milk powder. Membranes were incubated overnight at $4{ }^{\circ} \mathrm{C}$ with the appropriate primary antibody: anti-NF- $\kappa B$, p65 subunit, diluted 1:1000 (Millipore, Billerica, MA, USA). The membranes were finally incubated with the peroxidase-conjugated secondary anti-rabbit antibody (1:5000) for $1 \mathrm{~h}$. The bound antibodies were detected by chemiluminescence (Bio-Rad, Milan, Italy). $\beta$-Actin was used as loading control. Images of the bands were digitized using an Epson Stylus SX405 scanner, and the densitometry analysis was performed using ImageJ software.

e) Statistical analysis: For each of the variables tested, two-way analysis of variance (ANOVA) was used. A significant result was indicated by $P<0.05$. All the results are expressed as mean $\pm S D$ of triplicate determinations obtained in three independent experiments. Data were analyzed using the software GraphPad Prism 4.0 (GraphPad Software, Inc., La Jolla, CA, USA).

\section{Pharmacological in vivo study}

a) Animals: Male CD-1 albino mice (Envigo, Varese, Italy) weighing approximately $22-25 \mathrm{~g}$ at the beginning of the experimental procedure were used. Animals were housed in CeSAL (Centro Stabulazione Animali da Laboratorio, University of Florence) and used at least one week after their arrival. Ten mice were housed per cage (size $26 \times 41 \mathrm{~cm}$ ); animals were fed a standard laboratory diet and tap water ad libitum, and kept at $23 \pm 1{ }^{\circ} \mathrm{C}$ with a $12 \mathrm{~h}$ light/dark cycle, light at 7:00. All animal manipulations were carried out according to the Directive 2010/63/EU of the European parliament and of the European Union council (22.September, 2010) on the protection of animals used for scientific purposes. The ethical policy of the University of Florence complies with the Guide for the Care and Use of Laboratory Animals of the US National Institutes of Health (NIH Publication No. 85-23, revised 1996; University of Florence assurance number: A5278-01). Formal approval to conduct the experiments described was obtained from the Animal Subjects Review Board of the University of Florence. Experiments involving animals have been reported according to ARRIVE guidelines. All efforts were made to minimize animal suffering and to minimize the number of animals used.

b) Oxaliplatin-induced neuropathic pain model and compound administration: Oxaliplatin $\left(2.4 \mathrm{mg} \mathrm{kg}^{-1}\right)$ was dissolved in $5 \% \mathrm{glu}-$ cose solution and administered i.p. for five consecutive days every week for two weeks. ${ }^{[40]}$ On day 14 , compounds $\mathbf{3}, \mathbf{5} \mathbf{h}$, and $\mathbf{5} \mathbf{i}$ were administered p.o. ${ }^{[47-48]}$ using $1 \%$ carboxymethylcellulose (CMC) as vehicle.

c) Cold plate test: The animals were placed in a stainless steel box $(12 \mathrm{~cm} \times 20 \mathrm{~cm} \times 10 \mathrm{~cm})$ with a cold plate as floor. The temperature of the cold plate was kept constant at $4 \pm 1{ }^{\circ} \mathrm{C}$. Pain-related behavior (licking of the hind paw) was observed, and the time (s) of the 
first sign was recorded. The cutoff time of the latency of paw lifting or licking was set at $60 \mathrm{~s} .{ }^{[49]}$ Measurements were performed before and $15,30,45$, and 60 min after compound administration.

d) Statistical analysis: Behavioral measurements were performed on 12 mice for each treatment carried out in two different experimental sets. Results are expressed as mean \pm SEM. The analysis of variance of behavioral data was performed by one-way ANOVA, and Bonferroni's significant difference procedure was used as posthoc comparison. $P$ values less than 0.05 or 0.01 were considered significant. Investigators were blind to all experimental procedures. Data were analyzed using the Origin 9 software package (OriginLab, Northampton, USA).

\section{Abbreviations}

AEA: anandamide; CBR: cannabinoid receptor; CMC: carboxymethylcellulose; CNS: central nervous system; 1,2-DCE: 1,2-dichloroethane; DMF: N,N-dimethylformamide; DMSO: dimethyl sulfoxide; ECs: endocannabinoids; FAAH: fatty acid amide hydrolase; FAEs: fatty acid ethanolamides; $L D H$ : lactate dehydrogenase; MAGL: monoacylglycerol lipase; PDB: Protein Data Bank; SAR: structureactivity relationship; TEA: triethylamine; THF: tetrahydrofuran.

\section{Acknowledgements}

The authors thank the Ministry of Education, Universities and Research (MIUR Italy) PRIN 20088SPEFN_005 for research funding.

\section{Conflict of interest}

The authors declare no conflict of interest.

Keywords: covalent inhibitors - endocannabinoid system fatty acid amide hydrolase - neuropathic pain ' serine hydrolase

[1] M. P. Patricelli, B. F. Cravatt, Biochemistry 1999, 38, 14125-14130.

[2] D. K. Giang, B. F. Cravatt, Proc. Natl. Acad. Sci. USA 1997, 94, 2238-2242.

[3] M. P. Patricelli, M. A. Lovato, B. F. Cravatt, Biochemistry 1999, 38, $9804-$ 9812.

[4] K. Tsuboi, Y. X. Sun, Y. Okamoto, N. Araki, T. Tonai, N. Ueda, J. Biol. Chem. 2005, 280, $11082-11092$.

[5] M. Karlsson, J. A. Contreras, U. Hellman, H. Tornqvist, C. Holm, J. Biol. Chem. 1997, 272, 27218-27223.

[6] W. A. Devane, L. Hanus, A. Breuer, R. G. Pertwee, L. A. Stevenson, G. Griffin, D. Gibson, A. Mandelbaum, A. Etinger, R. Mechoulam, Science 1992, 258, 1946- 1949.

[7] R. Mechoulam, S. Ben-Shabat, L. Hanus, M. Ligumsky, N. E. Kaminski, A. R. Schatz, A. Gopher, S. Almog, B. R. Martin, D. R. Compton, R. G. Pertwee, G. Griffin, M. Bayewitch, J. Barg, Z. Vogel, Biochem. Pharmacol. 1995, 50, $83-90$.

[8] J. Zias, H. Stark, J. Sellgman, R. Levy, E. Werker, A. Breuer, R. Mechoulam, Nature 1993, 363, 215.

[9] A. H. Lichtman, C. C. Shelton, T. Advani, B. F. Cravatt, Pain 2004, 109, $319-327$.

[10] F. Massa, G. Marsicano, H. Hermann, A. Cannich, K. Monory, B. F. Cravatt, G. L. Ferri, A. Sibaev, M. Storr, B. Lutz, J. Clin. Invest. 2004, 113, $1202-$ 1209.

[11] S. Huitron-Resendiz, M. Sanchez-Alavez, D. N. Wills, B. F. Cravatt, S. J. Henriksen, Sleep 2004, 27, 857-865.

[12] S. A. Varvel, L. E. Wise, F. Niyuhire, B. F. Cravatt, A. H. Lichtman, Neuropsychopharmacology 2007, 32, $1032-1041$.
[13] M. Seierstad, J. G. Breitenbucher, J. Med. Chem. 2008, 51, 7327-7343.

[14] Y. Miyake, J. J. Keusch, L. Wang, M. Saito, D. Hess, X. Wang, B. J. Melancon, P. Helquist, H. Gut, P. Matthias, Nat. Chem. Biol. 2016, 12, 748-754.

[15] A. C. M. van Esbroeck, A. P. A. Janssen, A. B. Cognetta, 3rd, D. Ogasawara, G. Shpak, M. van der Kroeg, V. Kantae, M. P. Baggelaar, F. M. S. de Vrij, H. Deng, M. Allara, F. Fezza, Z. Lin, T. van der Wel, M. Soethoudt, E. D. Mock, H. den Dulk, I. L. Baak, B. I. Florea, G. Hendriks, L. De Petrocellis, H. S. Overkleeft, T. Hankemeier, C. I. De Zeeuw, V. Di Marzo, M. Maccarrone, B. F. Cravatt, S. A. Kushner, M. van der Stelt, Science 2017, 356, 1084- 1087.

[16] M. Duenas, B. Ojeda, A. Salazar, J. A. Mico, I. Failde, J. Pain Res. 2016, 9, $457-467$.

[17] B. K. Lau, C. W. Vaughan, Front. Pharmacol. 2014, 5, 28.

[18] M. H. Bracey, M. A. Hanson, K. R. Masuda, R. C. Stevens, B. F. Cravatt, Science 2002, 298, $1793-1796$.

[19] G. Tarzia, A. Duranti, A. Tontini, G. Piersanti, M. Mor, S. Rivara, P. V. Plazzi, C. Park, S. Kathuria, D. Piomelli, J. Med. Chem. 2003, 46, 2352- 2360.

[20] J. P. Alexander, B. F. Cravatt, Chem. Biol. 2005, 12, 1179-1187.

[21] D. L. Boger, H. Miyauchi, W. Du, C. Hardouin, R. A. Fecik, H. Cheng, I. Hwang, M. P. Hedrick, D. Leung, O. Acevedo, C. R. Guimaraes, W. L. Jorgensen, B. F. Cravatt, J. Med. Chem. 2005, 48, 1849-1856.

[22] S. Butini, M. Brindisi, S. Gemma, P. Minetti, W. Cabri, G. Gallo, S. Vincenti, E. Talamonti, F. Borsini, A. Caprioli, M. A. Stasi, S. Di Serio, S. Ros, G. Borrelli, S. Maramai, F. Fezza, G. Campiani, M. Maccarrone, J. Med. Chem. 2012, 55, 6898-6915.

[23] S. Butini, S. Gemma, M. Brindisi, S. Maramai, P. Minetti, D. Celona, R. Napolitano, F. Borsini, W. Cabri, F. Fezza, L. Merlini, S. Dallavalle, G. Campiani, M. Maccarrone, Bioorg. Med. Chem. Lett. 2013, 23, 492- 495.

[24] M. Brindisi, S. Maramai, S. Gemma, S. Brogi, A. Grillo, L. Di Cesare Mannelli, E. Gabellieri, S. Lamponi, S. Saponara, B. Gorelli, D. Tedesco, T. Bonfiglio, C. Landry, K. M. Jung, A. Armirotti, L. Luongo, A. Ligresti, F. Piscitelli, C. Bertucci, M. P. Dehouck, G. Campiani, S. Maione, C. Ghelardini, A. Pittaluga, D. Piomelli, V. Di Marzo, S. Butini, J. Med. Chem. 2016, 59, $2612-2632$.

[25] M. Brindisi, S. Brogi, S. Maramai, A. Grillo, G. Borrelli, S. Butini, E. Novellino, M. Allara, A. Ligresti, G. Campiani, V. Di Marzo, S. Gemma, RSC Adv. 2016, 6, 64651-64664.

[26] J. Lim, M. Igarashi, K. M. Jung, S. Butini, G. Campiani, D. Piomelli, Neuropsychopharmacology 2016, 41, 1329-1339.

[27] R. Colangeli, M. Pierucci, A. Benigno, G. Campiani, S. Butini, G. Di Giovanni, Sci. Rep. 2017, 7, 11152.

[28] G. Campiani, A. Cappelli, V. Nacci, M. Anzini, S. Vomero, M. Hamon, A Cagnotto, C. Fracasso, C. Uboldi, S. Caccia, S. Consolo, T. Mennini, J. Med. Chem. 1997, 40, 3670-3678.

[29] S. Butini, R. Budriesi, M. Hamon, E. Morelli, S. Gemma, M. Brindisi, G. Borrelli, E. Novellino, I. Fiorini, P. Ioan, A. Chiarini, A. Cagnotto, T. Mennini, C. Fracasso, S. Caccia, G. Campiani, J. Med. Chem. 2009, 52, $6946-$ 6950.

[30] E. Morelli, S. Gemma, R. Budriesi, G. Campiani, E. Novellino, C. Fattorusso, B. Catalanotti, S. S. Coccone, S. Ros, G. Borrelli, M. Persico, I. Fiorini, V. Nacci, P. Ioan, A. Chiarini, M. Hamon, A. Cagnotto, T. Mennini, C. Fracasso, M. Colovic, S. Caccia, S. Butini, J. Med. Chem. 2009, 52, $3548-$ 3562.

[31] A. Cappelli, S. Butini, A. Brizzi, S. Gemma, S. Valenti, G. Giuliani, M. Anzini, L. Mennuni, G. Campiani, V. Brizzi, S. Vomero, Curr. Top. Med. Chem. 2010, 10, 504-526.

[32] M. Brindisi, S. Butini, S. Franceschini, S. Brogi, F. Trotta, S. Ros, A. Cagnotto, M. Salmona, A. Casagni, M. Andreassi, S. Saponara, B. Gorelli, P. Weikop, J. D. Mikkelsen, J. Scheel-Kruger, K. Sandager-Nielsen, E. Novellino, G. Campiani, S. Gemma, J. Med. Chem. 2014, 57, 9578-9597.

[33] S. Butini, M. Brindisi, S. Brogi, S. Maramai, E. Guarino, A. Panico, A. Saxena, V. Chauhan, R. Colombo, L. Verga, E. De Lorenzi, M. Bartolini, V. Andrisano, E. Novellino, G. Campiani, S. Gemma, ACS Med. Chem. Lett. 2013, 4, 1178-1182.

[34] M. Chioua, M. Perez, O. M. Bautista-Aguilera, M. Yanez, M. G. Lopez, A. Romero, R. Cacabelos, R. P. de la Bellacasa, S. Brogi, S. Butini, J. I. Borrell, J. Marco-Contelles, Mini-Rev. Med. Chem. 2015, 15, 648-658.

[35] M. Y. Wu, G. Esteban, S. Brogi, M. Shionoya, L. Wang, G. Campiani, M. Unzeta, T. Inokuchi, S. Butini, J. Marco-Contelles, Eur. J. Med. Chem. 2016, 121, 864-879. 
[36] C. Carrasco, M. Naziroglu, A. B. Rodriguez, J. A. Pariente, Front. Physiol. 2018, 9, 95.

[37] L. Di Cesare Mannelli, M. Zanardelli, P. Failli, C. Ghelardini, J. Pain 2012 $13,276-284$.

[38] S. Brogi, A. Ramunno, L. Savi, G. Chemi, G. Alfano, A. Pecorelli, E. Pambianchi, P. Galatello, G. Compagnoni, F. Focher, G. Biamonti, G. Valacchi, S. Butini, S. Gemma, G. Campiani, M. Brindisi, Eur. J. Med. Chem. 2017, $138,438-457$.

[39] L. Di Cesare Mannelli, A. Pacini, L. Bonaccini, M. Zanardelli, T. Mello, C. Ghelardini, J. Pain 2013, 14, 1585-1600.

[40] G. Cavaletti, G. Tredici, M. G. Petruccioli, E. Donde, P. Tredici, P. Marmiroli, C. Minoia, A. Ronchi, M. Bayssas, G. G. Etienne, Eur. J. Cancer 2001, 37, 2457-2463.

[41] W. L. Jorgensen, D. S. Maxwell, J. Tirado-Rives, J. Am. Chem. Soc. 1996 $118,11225-11236$

[42] W. C. Still, A. Tempczyk, R. C. Hawley, T. Hendrickson, J. Am. Chem. Soc. 1990, 112, 6127-6129.

[43] M. Mileni, J. Garfunkle, C. Ezzili, B. F. Cravatt, R. C. Stevens, D. L. Boger, J. Am. Chem. Soc. 2011, 133, 4092-4100.

[44] S. Montanari, L. Scalvini, M. Bartolini, F. Belluti, S. Gobbi, V. Andrisano, A Ligresti, V. Di Marzo, S. Rivara, M. Mor, A. Bisi, A. Rampa, J. Med. Chem. 2016, 59, 6387-6406.
[45] G. Ortar, T. Bisogno, A. Ligresti, E. Morera, M. Nalli, V. Di Marzo, J. Med. Chem. 2008, 51, 6970-6979.

[46] N. A. Osman, A. Ligresti, C. D. Klein, M. Allara, A. Rabbito, V. Di Marzo K. A. Abouzid, A. H. Abadi, Eur. J. Med. Chem. 2016, 122, 619-634.

[47] C. Battilocchio, G. Poce, S. Alfonso, G. C. Porretta, S. Consalvi, L. Sautebin, S. Pace, A. Rossi, C. Ghelardini, L. Di Cesare Mannelli, S. Schenone, A. Giordani, L. Di Francesco, P. Patrignani, M. Biava, Bioorg. Med. Chem. 2013, 21, 3695-3701.

[48] M. Anzini, S. Valenti, C. Braile, A. Cappelli, S. Vomero, S. Alcaro, F Ortuso, L. Marinelli, V. Limongelli, E. Novellino, L. Betti, G. Giannaccini, A. Lucacchini, S. Daniele, C. Martini, C. Ghelardini, L. Di Cesare Mannelli, G. Giorgi, M. P. Mascia, G. Biggio, J. Med. Chem. 2011, 54, 5694-5711.

[49] L. Di Cesare Mannelli, A. Pacini, F. Corti, S. Boccella, L. Luongo, E. Esposito, S. Cuzzocrea, S. Maione, A. Calignano, C. Ghelardini, PLoS One 2015 10, e0128080.

Manuscript received: June 12, 2018

Revised manuscript received: August 5, 2018

Accepted manuscript online: August 7, 2018

Version of record online: August 30, 2018 